
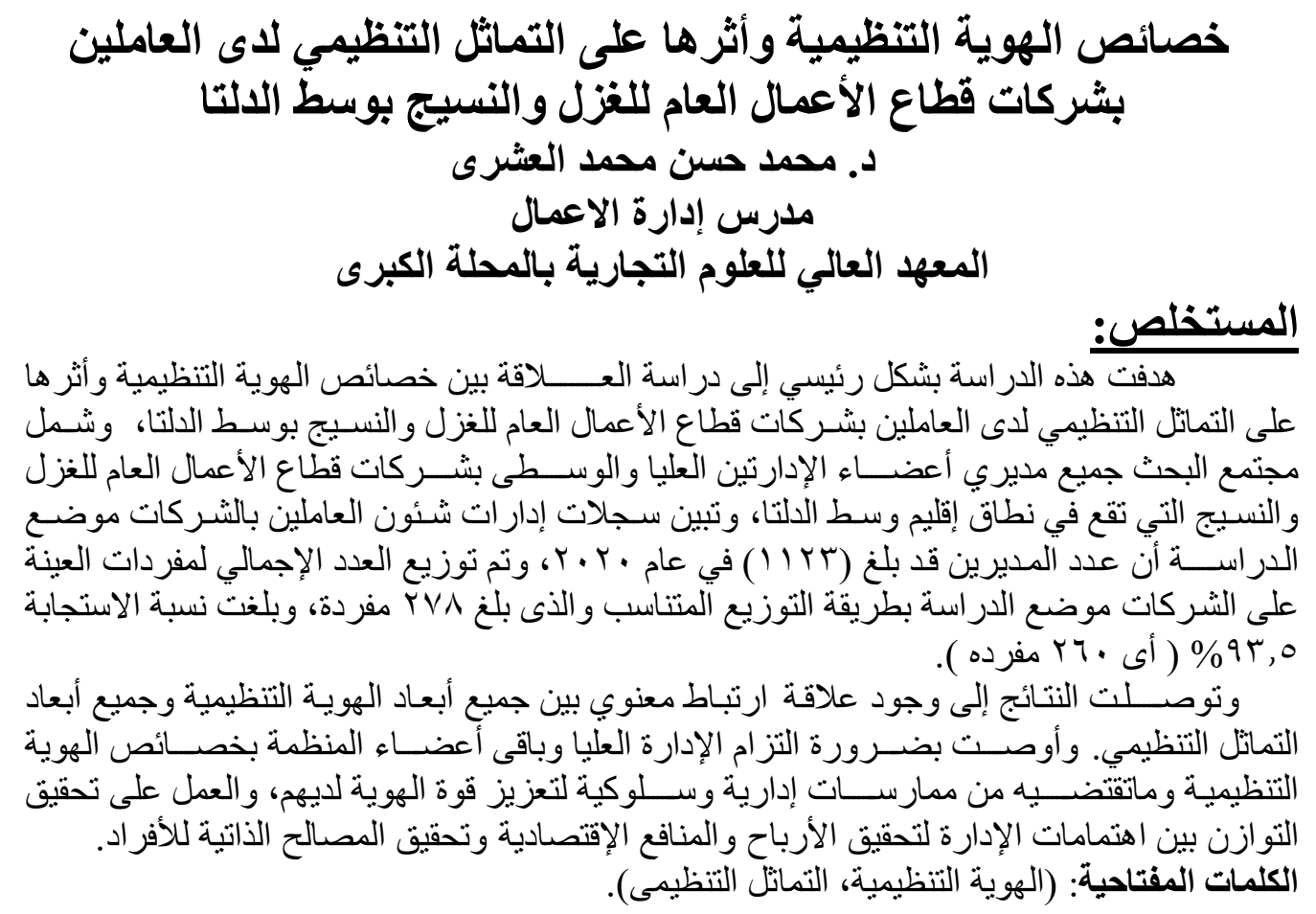

\title{
Abstract:
}

This study mainly aimed to study the relationship between the characteristics of the organizational identity and its impact on organizational symmetry among employees of public enterprise sector companies for spinning and weaving in the middle of the delta, and the research community included all managers of members of the upper and middle administrations of public enterprise sector companies for spinning and weaving that fall within the region of the central delta. The records of the personnel affairs departments of the companies under study show that the number of managers reached (1123) in 2020 , and the total number of the sample items was distributed among the companies under study in a proportional manner, which amounted to 278 individuals, and the response rate was $93.5 \%$ (i.e. 260 individuals).

The results found that there is a significant correlation relationship between all dimensions of organizational identity and all dimensions of organizational symmetry. It recommended the need for the higher management and the rest of the organization's members to adhere to the characteristics of the organizational identity and the administrative and behavioral practices required to enhance the strength of their identity, and to work to balance the interests of management to achieve profits and achieve the self-interests of individuals.

Key Words: (Organizational Identity, Organizational dentification).

تُعد الهوية التنظيمية Organizational Identity مفهوماً حديثاً نسبياً في مجال السلوك

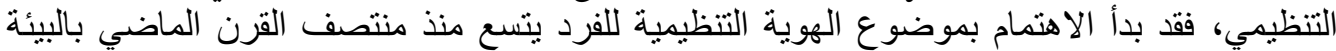

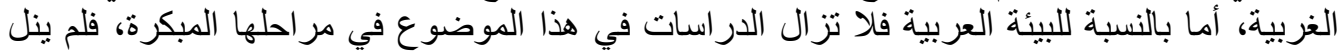

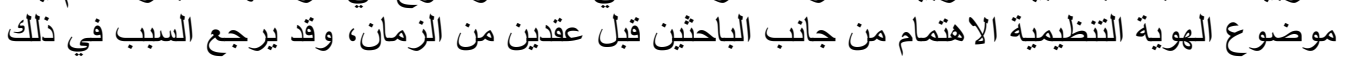

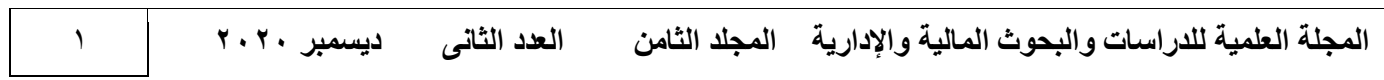


خصائص الهوية التظيمية وأثرها على التماثل التنظيمى لاى العاملين بثركات قطاع الأعمال العام للغزل والنسيج بوسط الدلتا

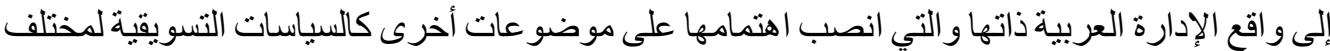

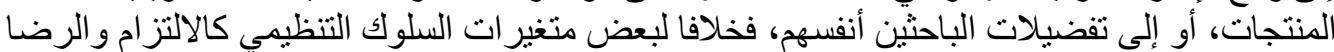

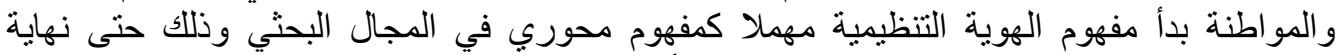

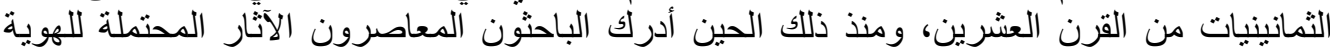

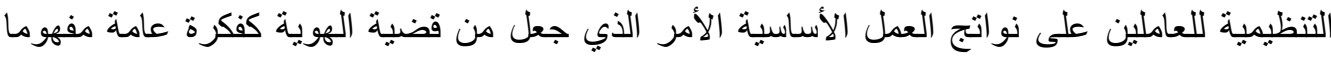

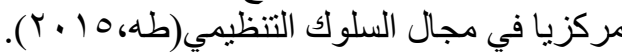

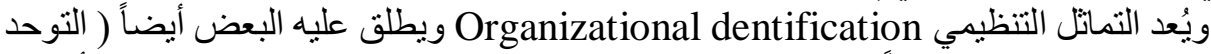

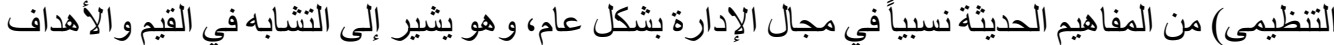

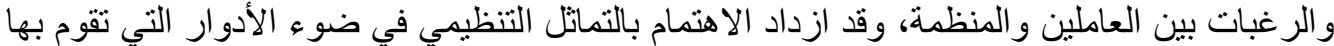

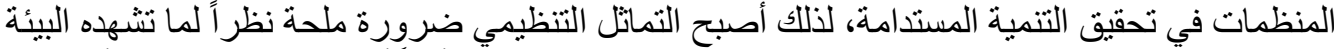

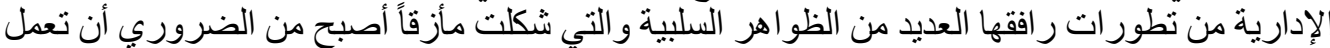

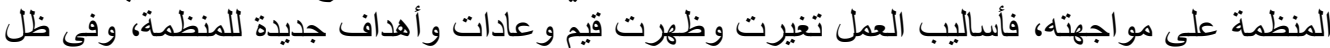

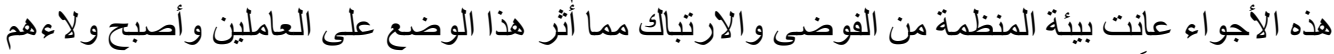

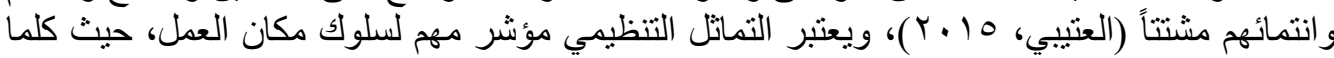

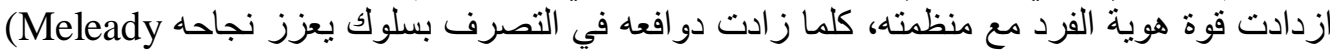
.and Crisp, 2017)

ويوجد اختلاف بين مصطلحي الهوية التنظيمية، و التماتل التنظيمي، حيث تمثل الهوبة التنظيمية تورية

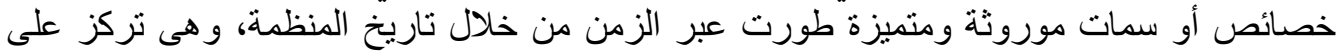

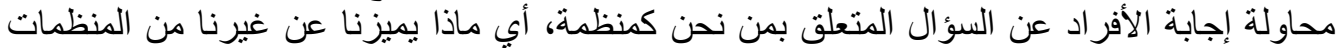

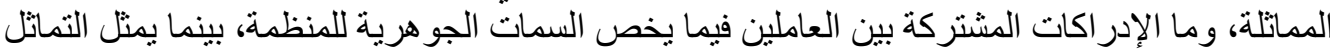

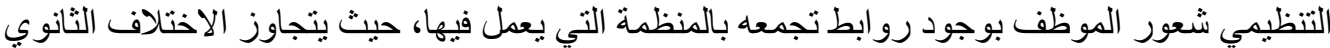

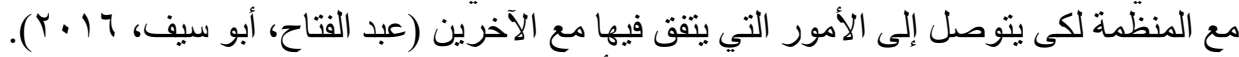

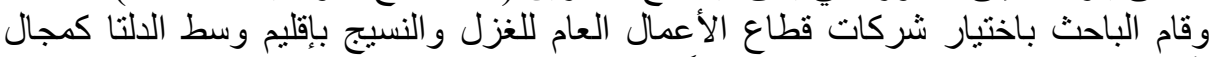

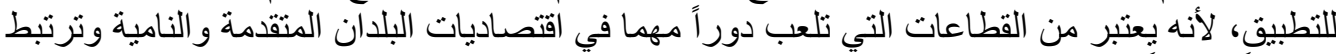

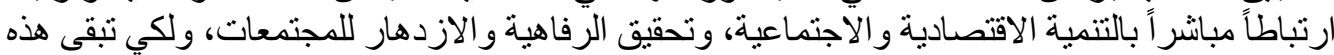

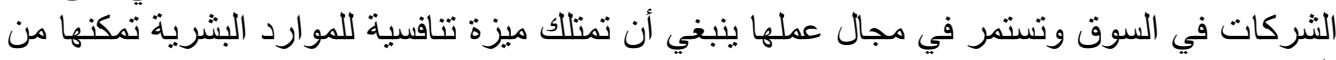

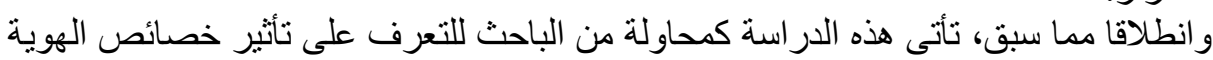

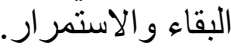

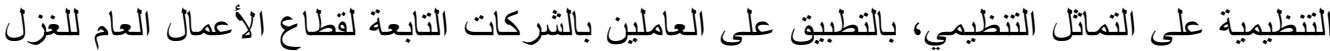

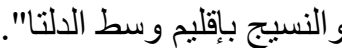

أولاً: الإطار النظرى والدراسات السابقة:

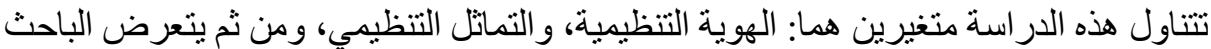

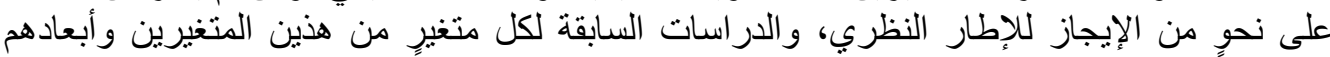

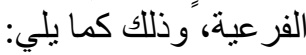

Organizational Identity المتفير الأول: الهوية التنظيمية: تناول الباحث متغير الهوية التنظيمية من خلال تسليط الضوء التية على مفهومها، وأبعادها،

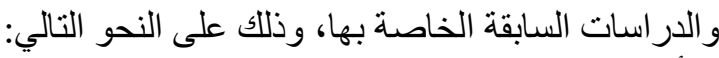

أ. أر مفهوم الهوية التظظيمية:

كثف العديد من الباحثين عن وجود العديد من التعريفات المتعلقة بالهوية التنظيمية، ويمكن

$$
\text { للباحث تحديد أهم هذه التعريفات فيما يلى: }
$$

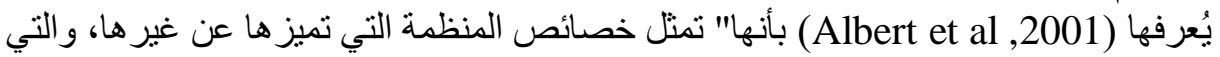

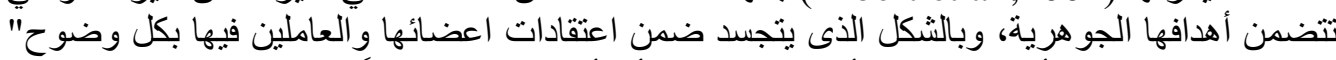

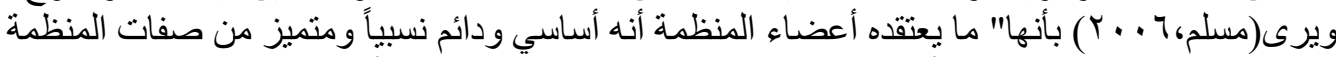

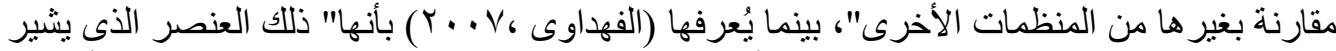

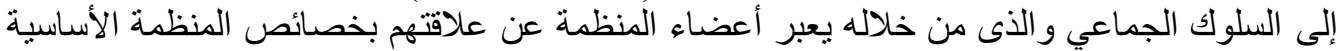

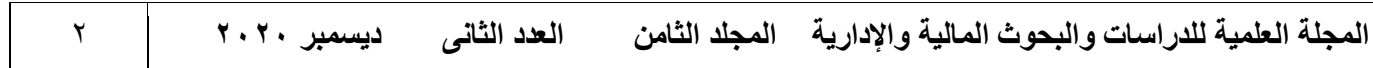


خصائص الهوية التظظيمية وأثرها على التماثل التظظيمى لاى العاملين بثركات قطاع الأعمال العام للغزل والنسيج بوسط الدلتا

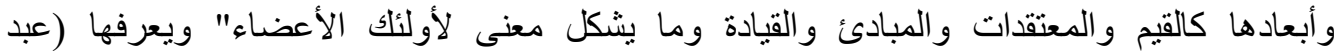

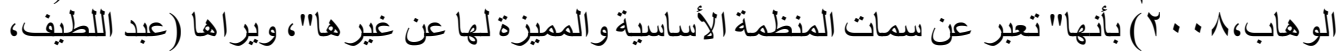

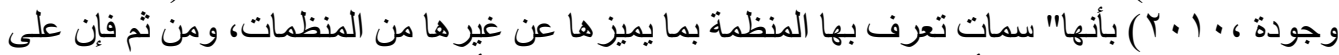

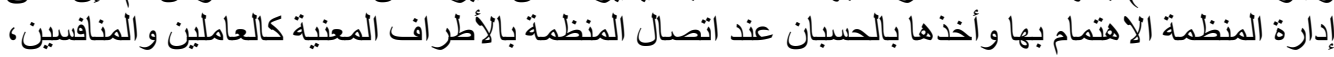

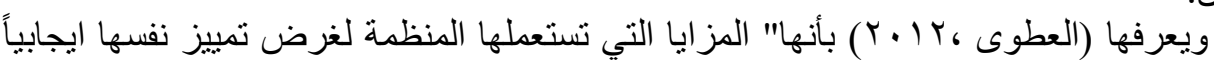

$$
\text { و الموردين. }
$$

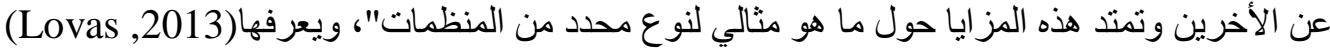

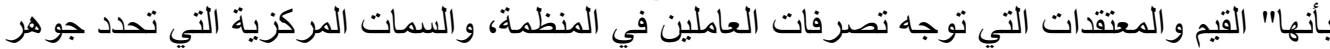

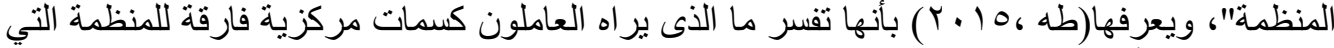

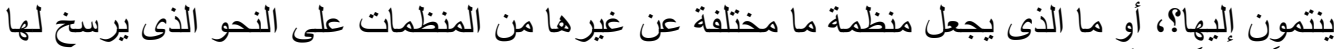

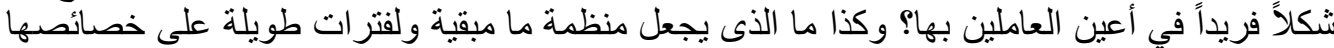
التنظيمية الفريدة بالر غم من التغير الذى بطرأ على الأهداف التنظيمية ذاتها؟"، كما يعرفها (عبد اللطيف

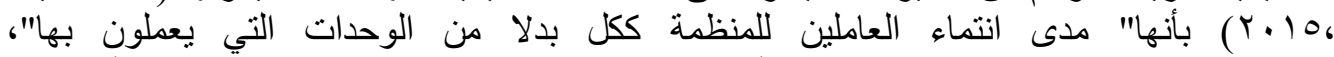

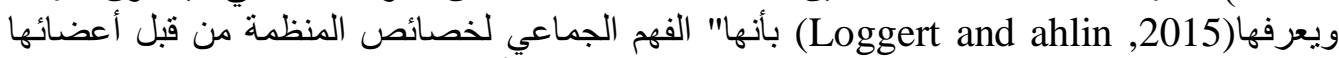

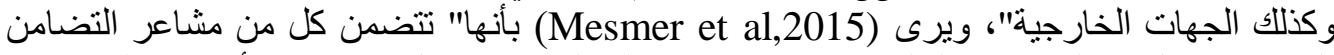

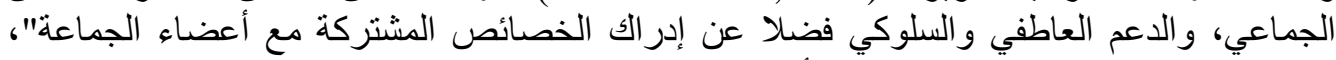

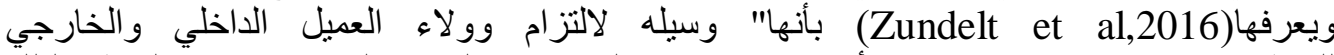

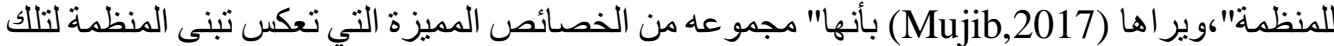

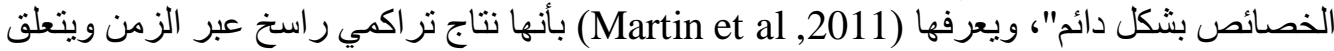

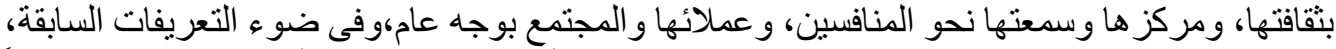
فإنه الباحث يتفق مع تعريف (طه ، (10 (Y)، وذللك على اعتبار أن هذا التعريف من أكثر التعريفات وضوحاً لماهية الهوية التنظيمية.

ب. باهُ أبعاد الهوية التنظيمية: بمر اجعة الباحث للعديد من أدبيات الدر اسات السابقة لاحظ اعنماد معظم هذه الأدئه الأبيات على قياس

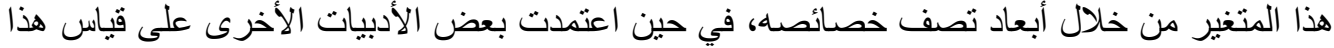

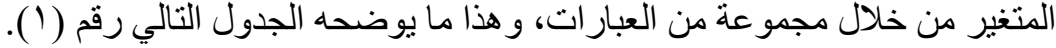

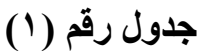

أبعاد الهوية التظظيمية كما تناولتها أدبيات الاراسات السابقة

\begin{tabular}{|c|c|c|c|c|c|c|c|c|c|c|}
\hline 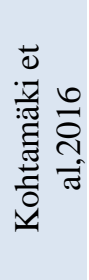 & 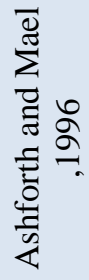 & 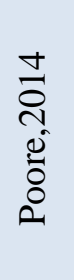 & 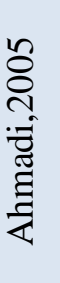 & 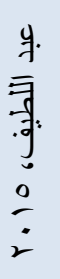 & $\begin{array}{l}\overline{3} \\
9 \\
y \\
2 \\
2\end{array}$ & 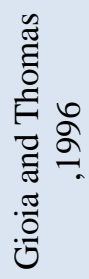 & $\begin{array}{l}\frac{q}{9} \\
\overline{3} \\
\frac{3}{3} \\
\underline{j} . \\
\vdots \\
\vdots\end{array}$ & $\begin{array}{l}\overline{7} \\
\frac{7}{9} \\
y \\
\vdots \\
\vdots \\
\vdots\end{array}$ & $\begin{array}{l}3 \\
3 \\
\vdots \\
\vdots\end{array}$ & المن \\
\hline & & & & & & $\checkmark$ & $\sqrt{ }$ & & $\checkmark$ & قوة الهوية \\
\hline & & & & & $\sqrt{ }$ & $\checkmark$ & $\checkmark$ & & $\checkmark$ & الهوية المعيارية \\
\hline & & & & & $\sqrt{ }$ & $\checkmark$ & $\checkmark$ & & $\checkmark$ & الهوية النفعية \\
\hline & & & & & & $\checkmark$ & $\sqrt{ }$ & & $\checkmark$ & الصورة الذهنية \\
\hline & & & & $\sqrt{ }$ & & & & & & السمات المركزية \\
\hline$\checkmark$ & $\checkmark$ & $\checkmark$ & $\checkmark$ & & & & & $\sqrt{ }$ & & مجمو عة من العبار ات \\
\hline
\end{tabular}

المصدر: إعداد الباحث اعتمادا على ما ورد في أدبيات الدراسات السابقة.

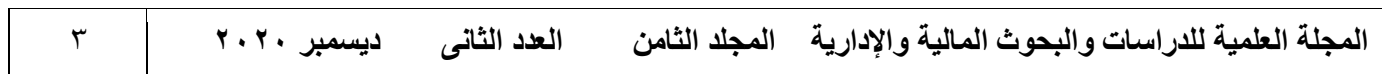


خصائص الهوية التظظيمية وأثرها على التماثل التظظيمى لاى العاملين بثركات قطاع الأعمال العام للغزل والنسيج بوسط الدلتا

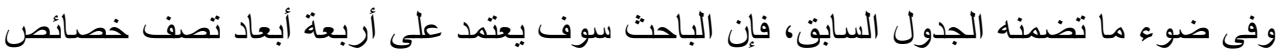

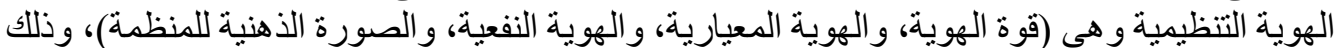

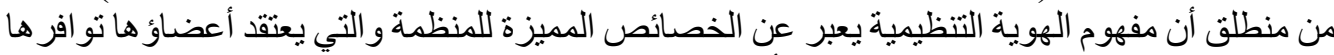

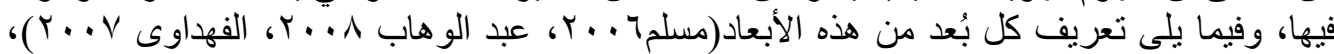
وذللك كما يلى:

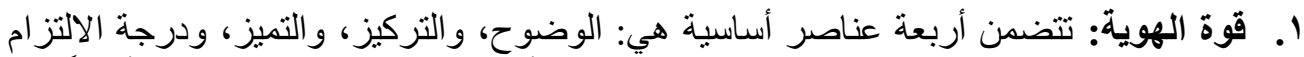

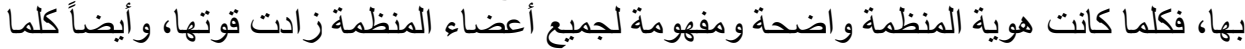

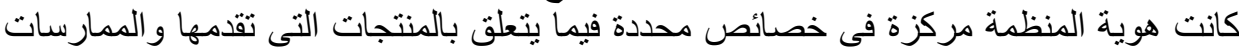

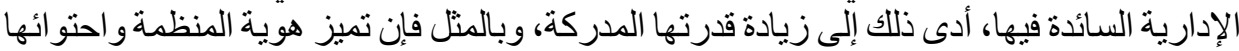

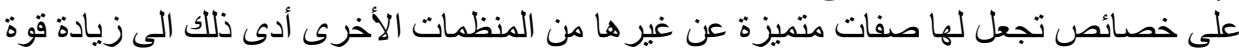

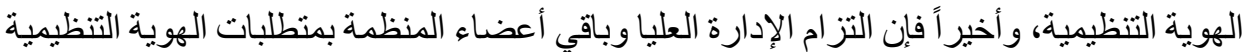

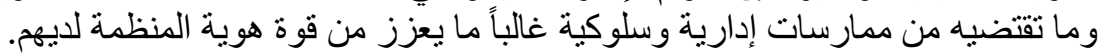

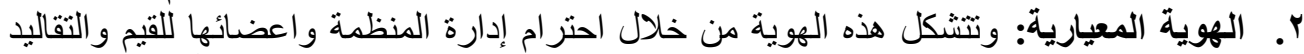

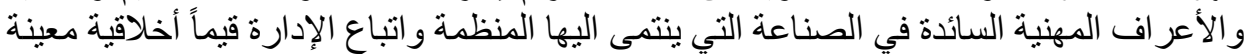

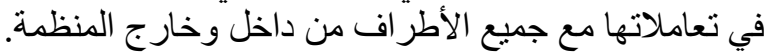

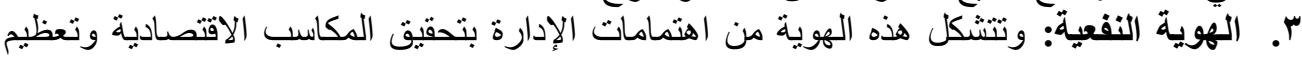

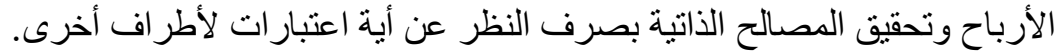

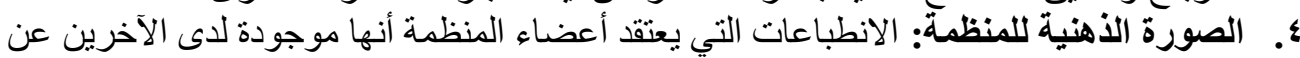
منظمتهم، ويقيس هذا المتغير القوة النسبية لهوية المنظمة كما يدركها العاملون بالمنظمة.

ج. الاراسات السابقة التي تتاولت الهوية التنظيمية.

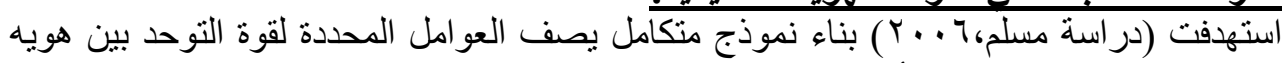

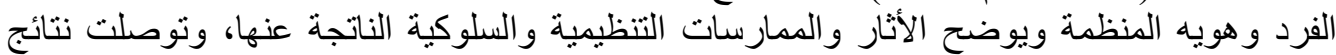
الدر اسة إلى وجود علاقه طردية بين قوة هوية المنظمة ودرجة التوحد التنظيمي لدى الافر اد العادية التملين بها.

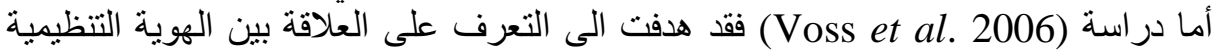

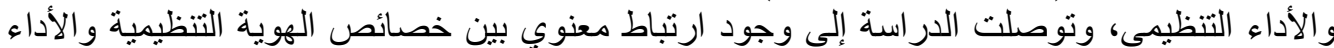
التنظيمي.

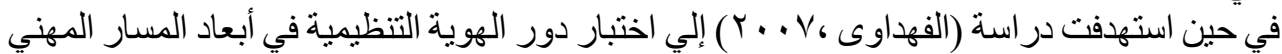

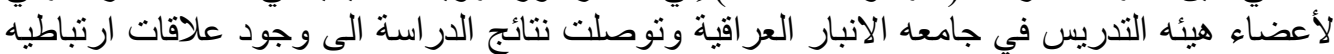

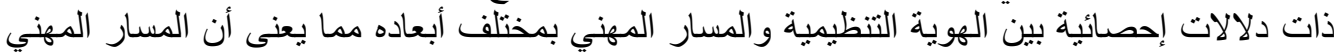

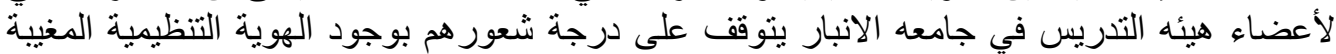
اصلا عن حياتهم الوظيفية و العملية.

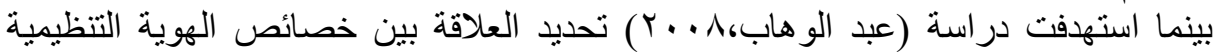

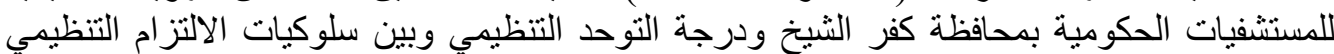

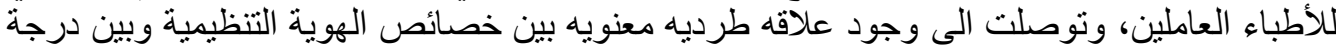

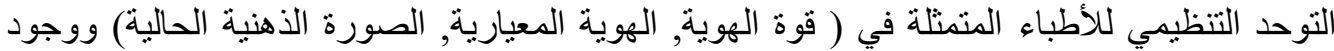
علاقه عكسيه بين الهوية النفعية ودرجة التوحد التنظيمي.

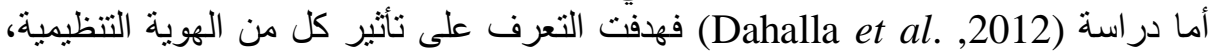

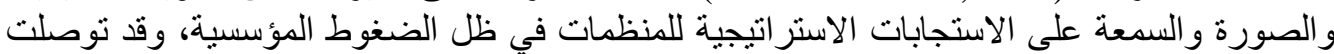
الدر اسة إلى وجود أثر معنوي لكل من الهوية التنظيمية، والصورة الإنية والسمعة على الاستجابات الاستر اتيجية

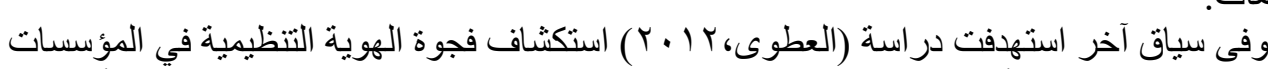
التعليمية العر اقية، وبيان تأثير حجم هذه الفجوة في احتماليه قبول مبادرات التغير ،وتوصلت الى أن نسبة التية

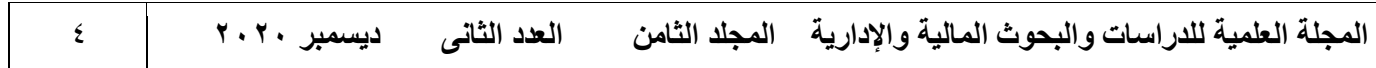


خصائص الهوية التظظيمية وأثرها على التماثل التظظيمى لاى العاملين بثركات قطاع الأعمال العام للغزل والنسيج بوسط الدلتا كبيرة بريدون أن تمتلك منظمتهم هويه تنظيميه عالية تهنم بكل من الجو انب المعيارية و الجوانب النفعية في العمل.

و على جانب آخر استهدفت دراسة (Kerwin, 2013) التعرف على أثر الهوية التظظيمية على التى

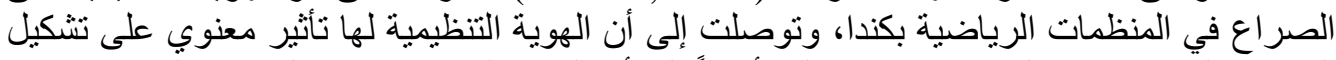

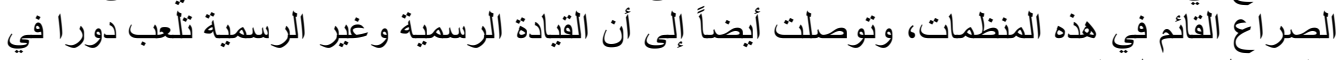

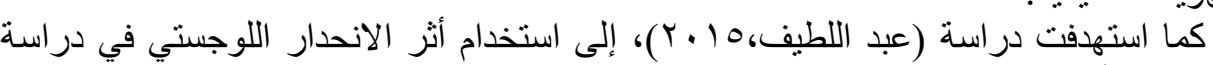
تطوير الهوية التنظيمبة التين علاقه ومعنويه تأثير المتغيرات الحاكمة لكل من الاغتر اب الوظيفي والاحتراق الوظة الوظيفي على الهوية

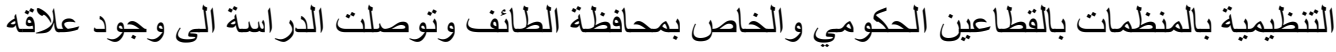

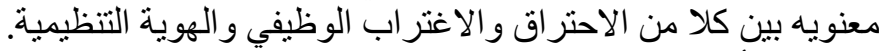

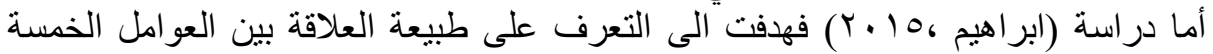

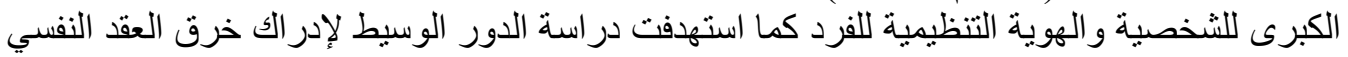

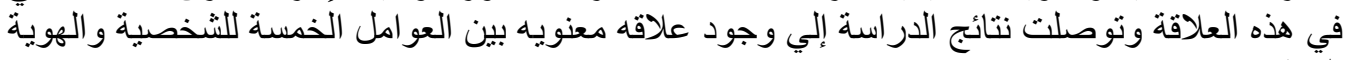
التنظيمية.

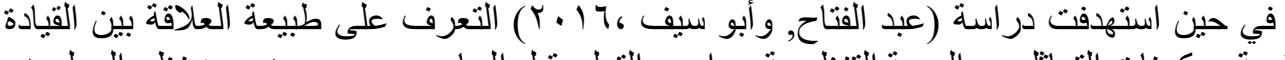

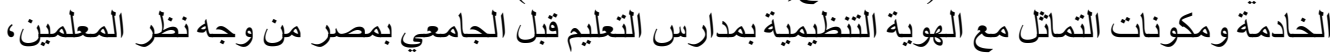

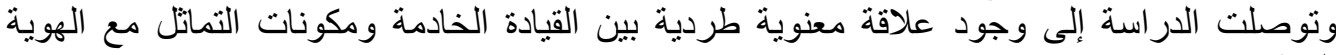
التتظبمية.

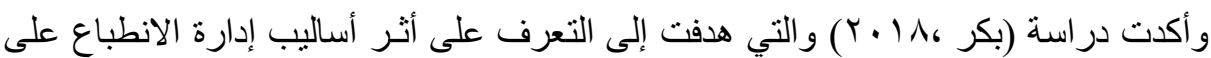

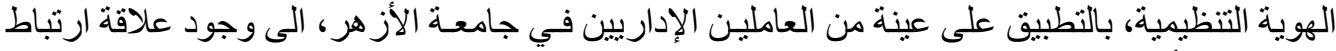

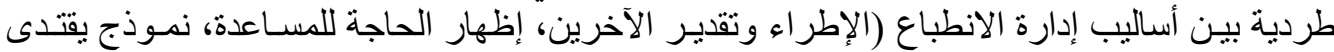

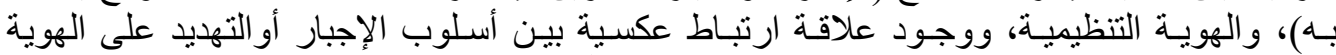

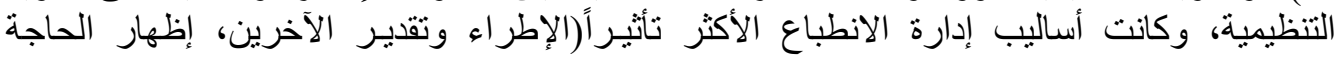
للمساعدة، نموذج بقتدى بـه). أما فيما يتعلق بتشكيل الهوية التنظيمية فقد استهدفت در اسة (جاد، 19 ( ب ) رصد كيفية تشكيل الهوية التظيمية لدى العاملين في شركات الاتصالات العاملة في مصر وتحديد مر احل نشكيل الهوية،

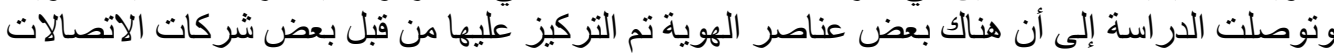

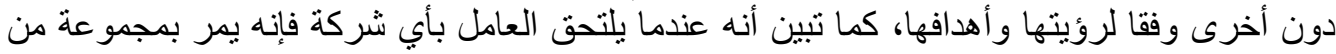

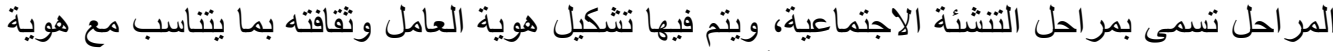

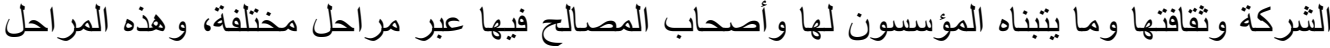

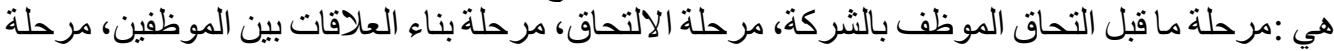

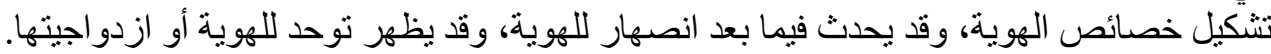

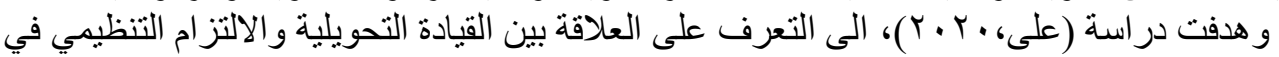

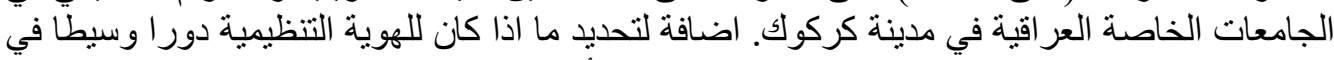

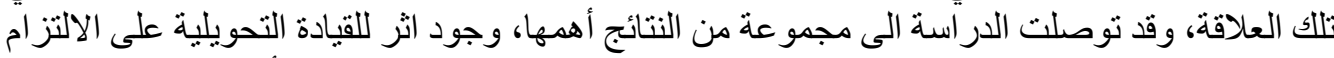

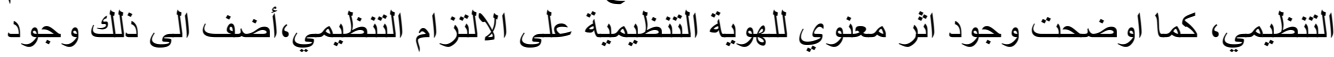
علاقة بين القيادة التحويلية والهيا والهوية التنظيمية.

\section{Organizational Identification}

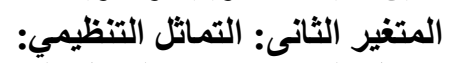

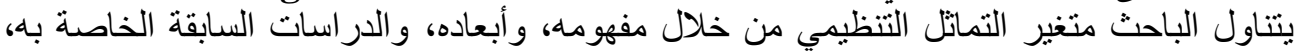
وذللك على النحو التالي:

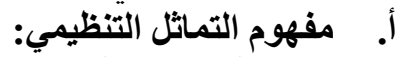

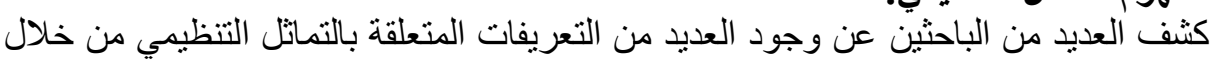

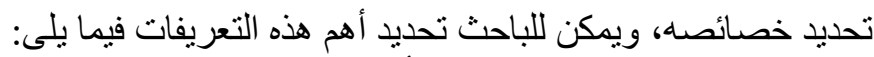

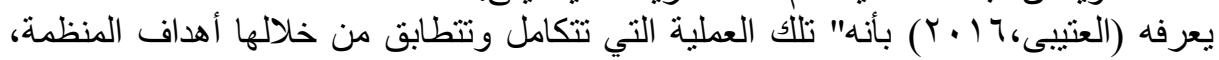

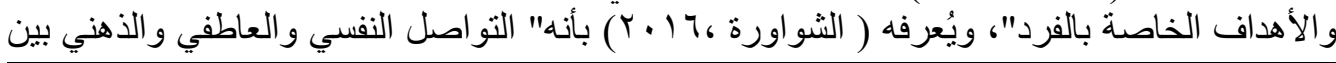

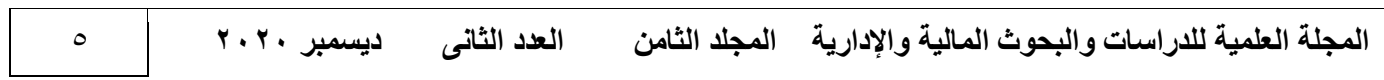


خصائص الهوية التظيمية وأثرها على التماثل التنظيمى لاى العاملين بثركات قطاع الأعمال العام للغزل والنسيج بوسط الدلتا

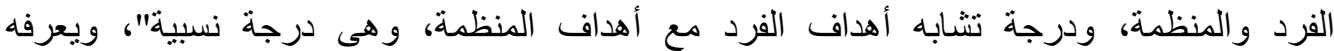

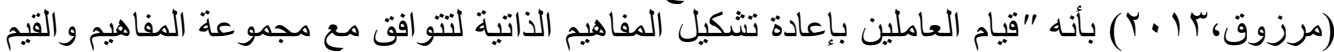

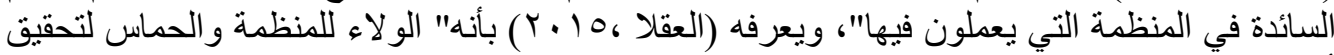

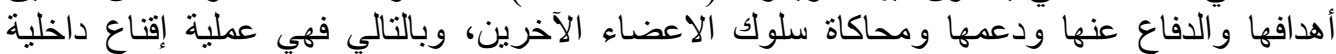

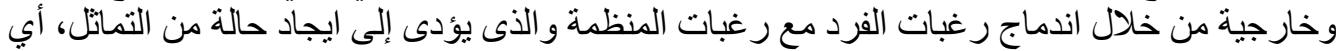

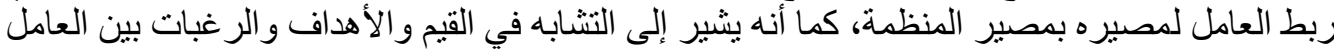

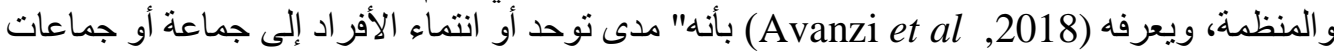
معينة"، ويعرفه (Wang et al ,2017) بأنه" شكل من أشكال هوية العمل، مشير ا إلى مدى تداخل هوية

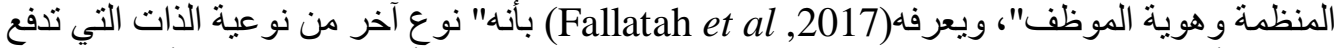

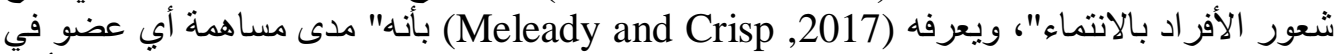

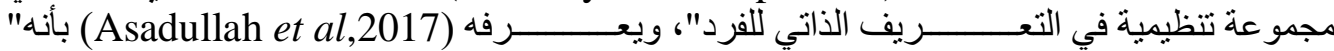

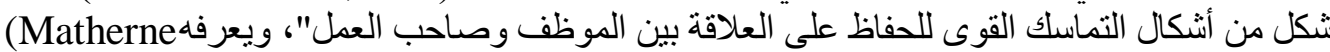
et al,2017) بأنه" التوحد مع المنظمة أو الانتماء لها كعامل مساهم في عدد من السلوكيات الإيجابية التي يظهر ها موظفين الشركة"، ويعرفه (Cavazotte et al, 2017) بأنّه" شكل محدد من أشكال الهوية الاجتماعية"، ويعرفه (Taşkıran et al, 2017) بأنه" الدرجة التي يعتبر فيها العاملون أنفسهم كجزء

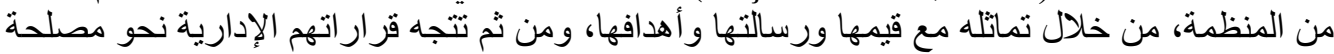
المنظمة" المنفة

وفى ضو هء التعريفات السابقة يمكن للباحث تعريف التماثل التنظيمي بأنه" شعور نابع من ذات

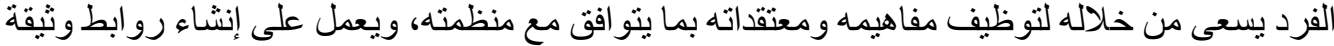

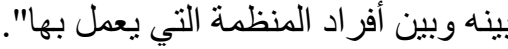

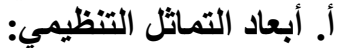

بمر اجعة الباحث "للعديد من أدبيات الدر اسات السابقة التي تناولت قباس التماثل التتظيمي، لاحظ

اعتماد معظم هذه الأدبيات على مقياس(Cheney ,1983) وقام بعد ذلك (Johnson et al ,1999)

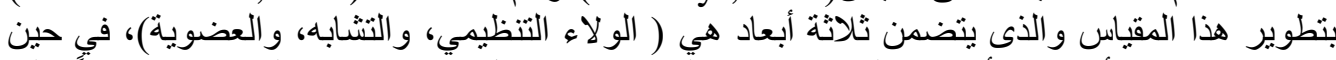

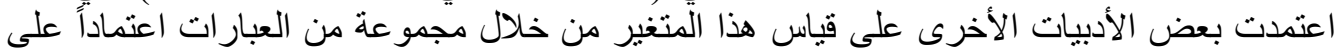

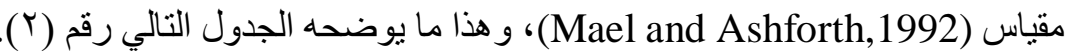

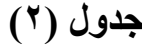

أبعاد التماثل التتظيمي كما تناولتها أدبيات الدرلاسات السابقة

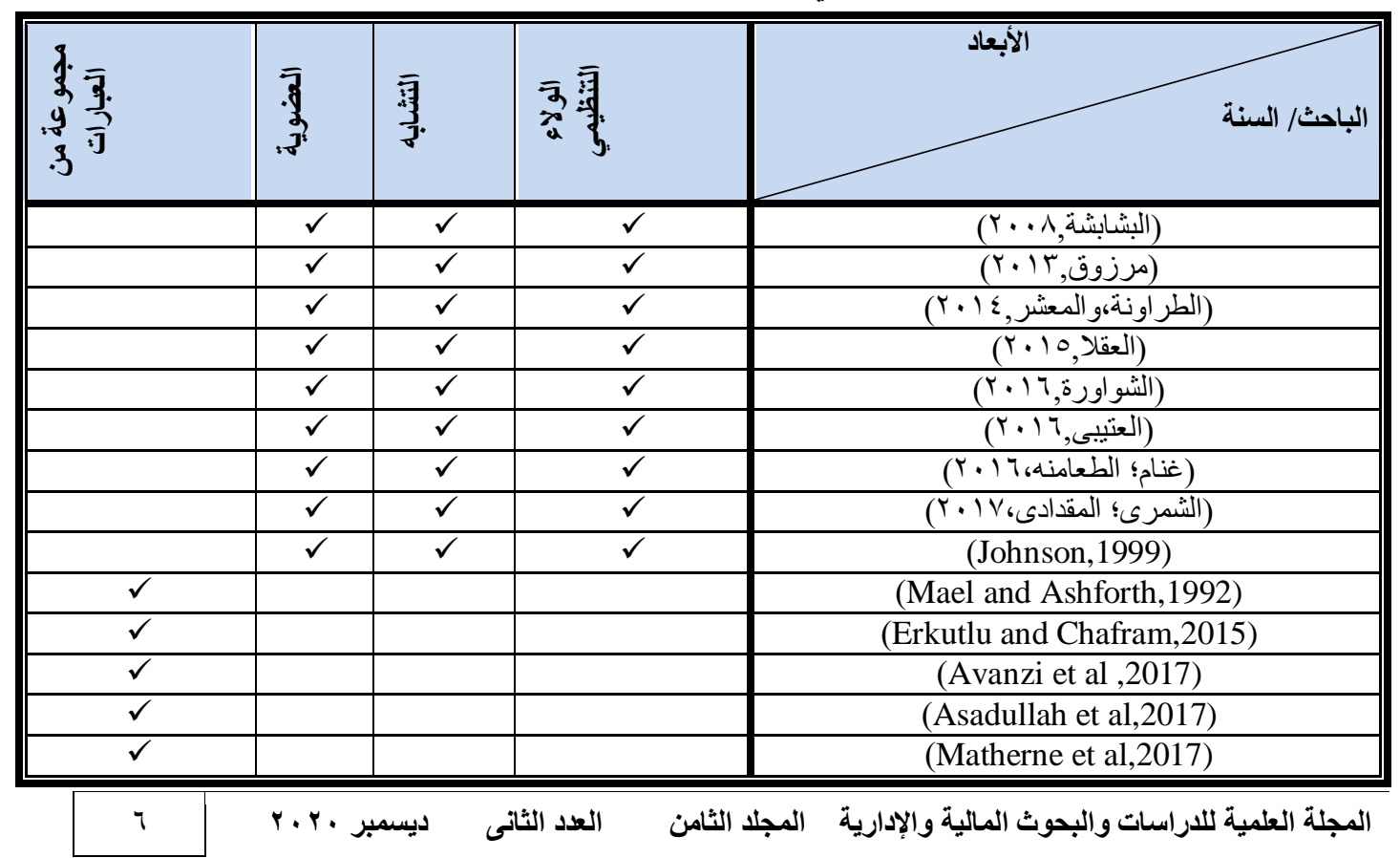


وفى ضوء ما تضمنه الجدول السابق، فإن الباحث سوف يعتمد على ثلاثة أبعاد لقياس التماثل

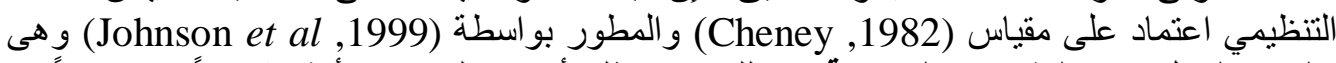

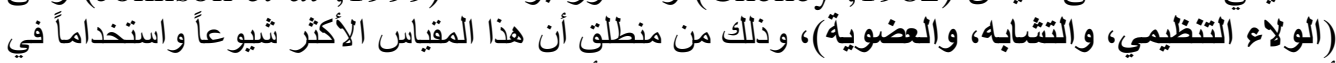
أدبيات الدر اسات السابقة، وفيما تعريف كل بُعد من هذه الأبعاد:

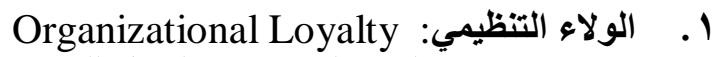
ويعبر عن مدى الدعم الذي يقدمه العامل للمنظمة و الحماس لتحقيق أهدافها والدفاع عنها ودعمها ومحاكاة سلوك الأعضاء الآخرين.

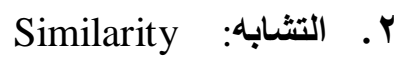
ويعني إدر الك الفرد لوجود خصائص وقيم و أهداف مشتركة مع الأعضاء الآخرين في المجمو عة أو المنظمة الني ينتمي إليها.

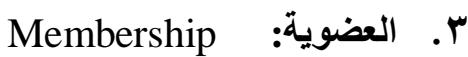
وتنبير إلى درجة فهم و إدر الك الفرد لذاته من حيث ارتباطه بالمنظمة، وإحساس بالانتماء وشعور

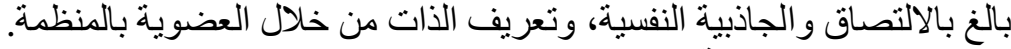

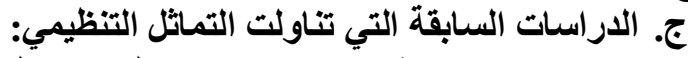

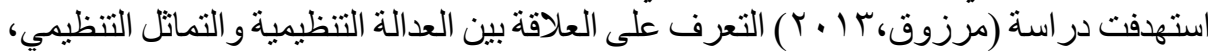

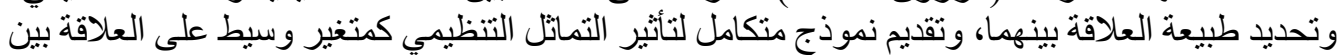

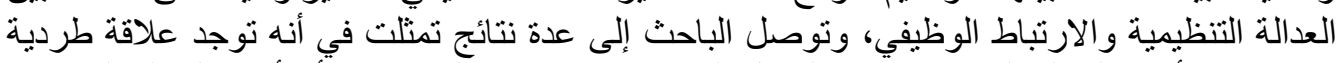

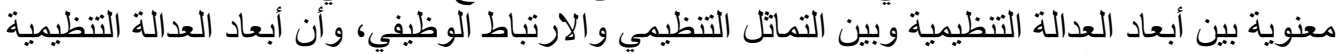
الثلاثة ترتبط معنو ياً بالتمانل التنظيمي.

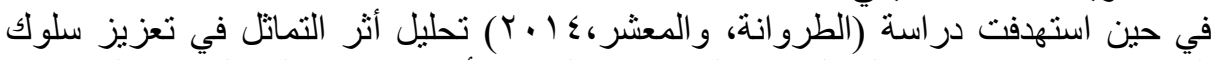

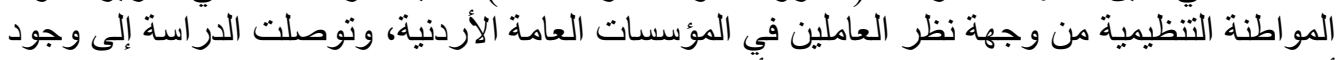

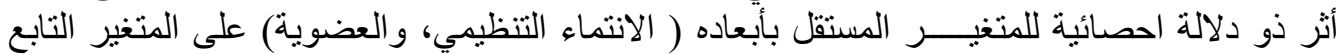

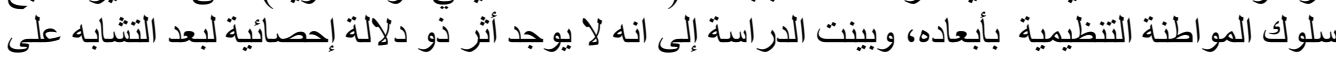
سلوك المواطنة التنظيمية.

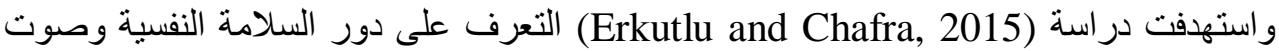

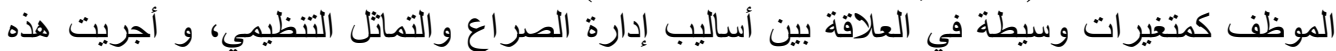

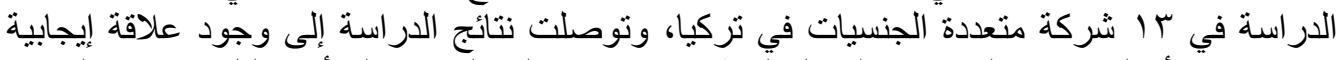

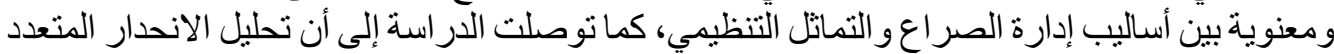

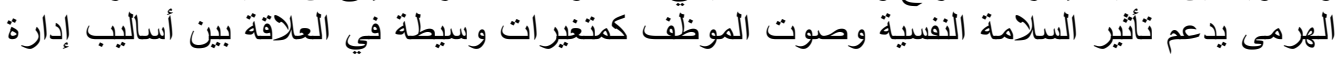

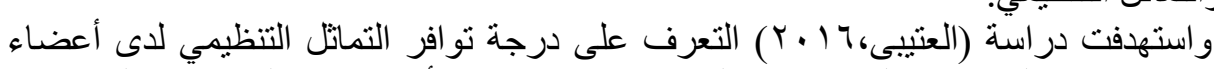

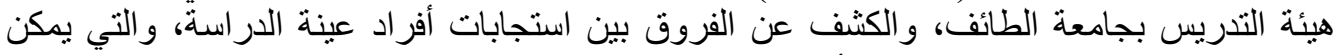

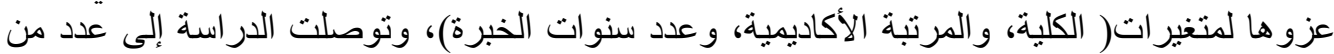

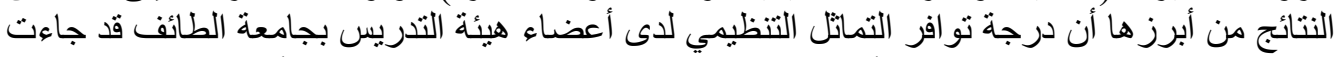

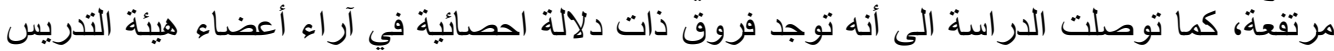

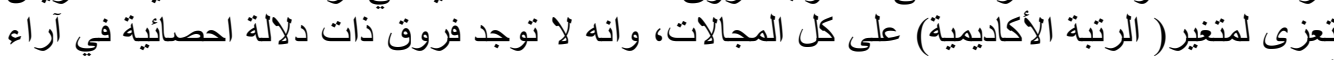

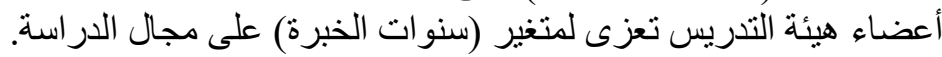

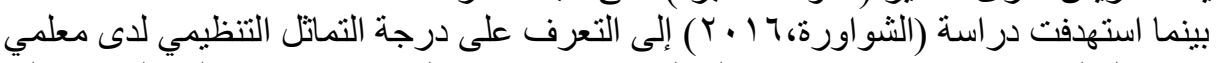

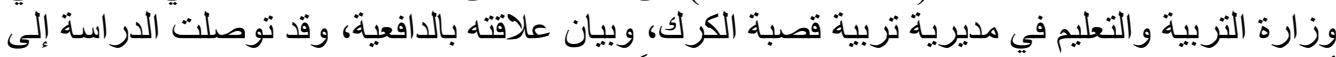

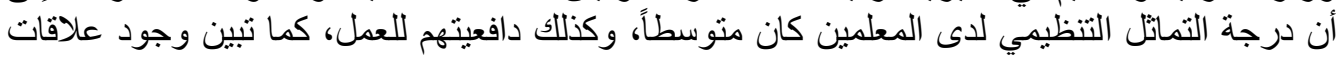
ذات دلالة احصائية بين كل من التماتل التنظيمي و الدافعية.

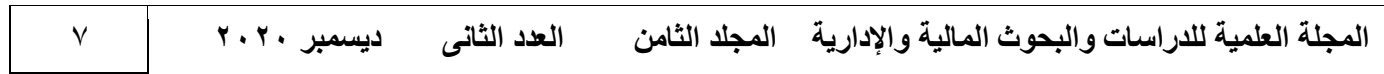


خصائص الهوية التظظيمية وأثرها على التماثل التظظيمى لاى العاملين بثركات قطاع الأعمال العام للغزل والنسيج بوسط الدلتا

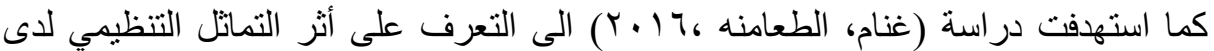

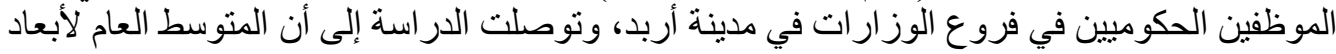

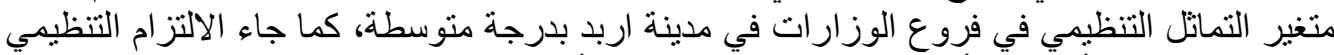

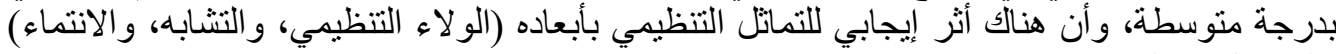
بينما استهدفت التظيت دراسة (الثمرى،و المقدادى V. V. التعرف على درجة ممارسة مديري على الالنز ام التظبيمي.

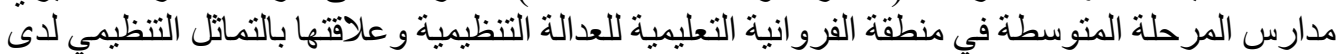

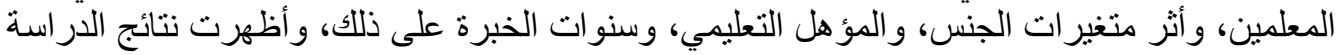

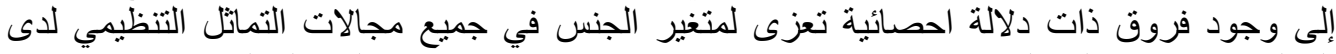
المعلمين، كما توصلت إلى وجود علاقة ايجابية بين ممارسة مديري مدارئ دارس المرحلة المتوسطة في منطقة

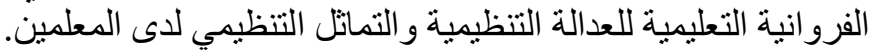

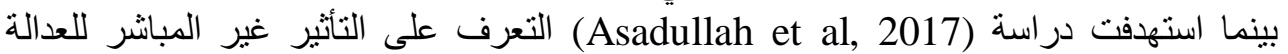

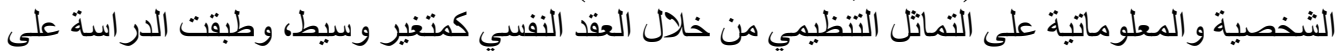

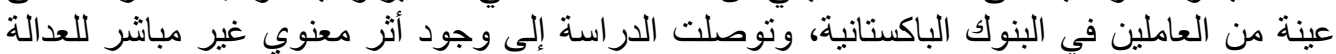

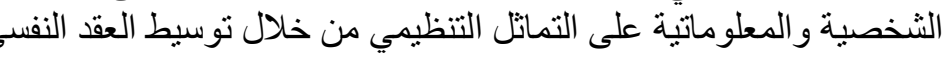

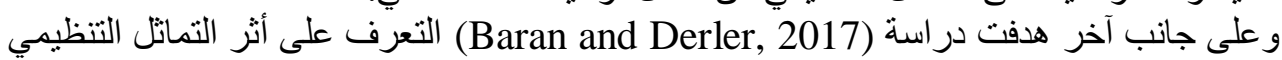

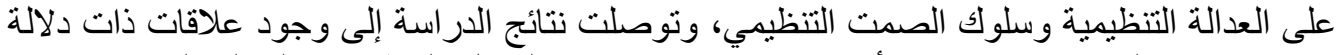
إحصائية بين المتغيرات، ووجود أثر إيجابي ومعنوي بين التماتل التنظيمي والعدالة التوزيعية، كما

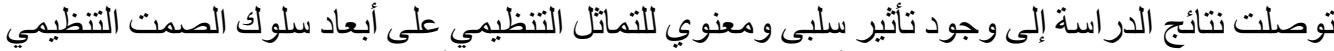

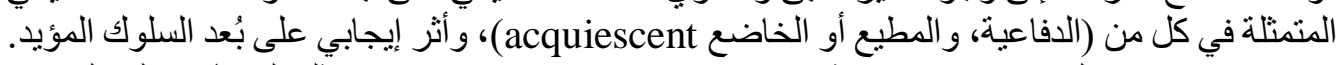
وفى سياق مختلف استهدفت در اسة (Cavazotte et al, 2017) فهم تماتثل الموظفين العاملين في

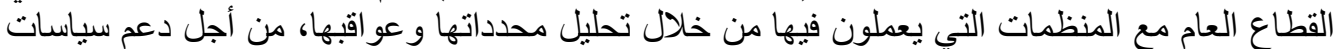

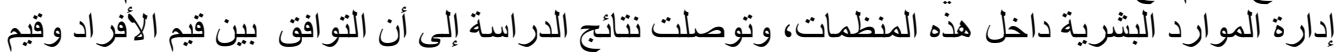

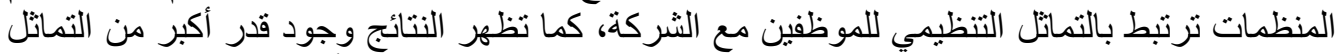

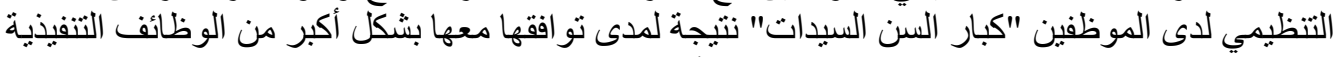

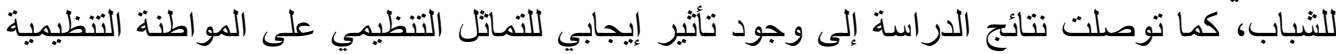

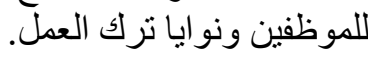
في حين استهدفت دراسة (Fallatah et al, 2017) اختبار أثر القيادة الأصبلة على نوايا دور ان

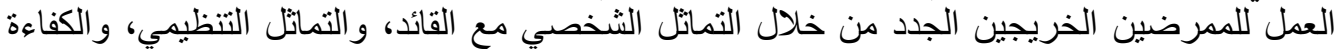

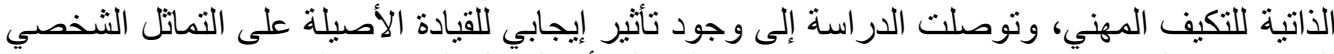

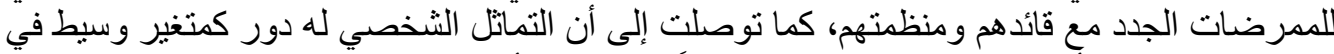

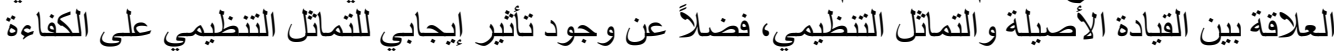

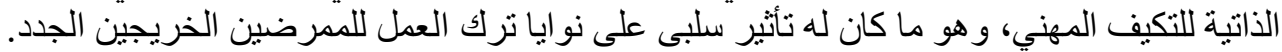

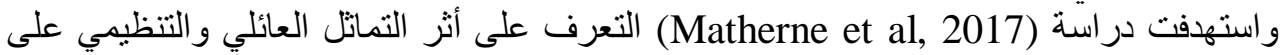

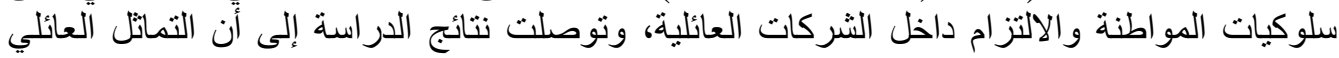

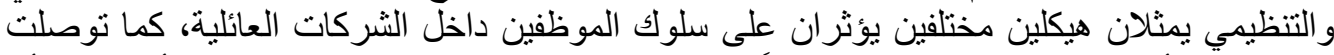

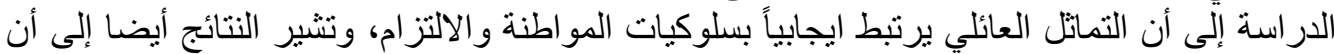
هذه العلاقة تتأثر بالعضوية في الأسرة المالكة. واستهدفت دراسة (Meleady and Crisp, 2017) وضع إطار لتعزيز التماثل التنظيمي على التهي

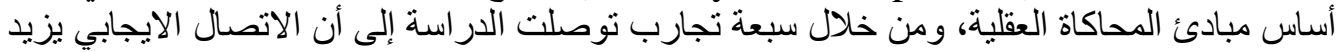

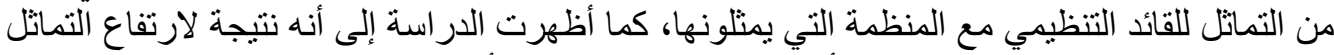

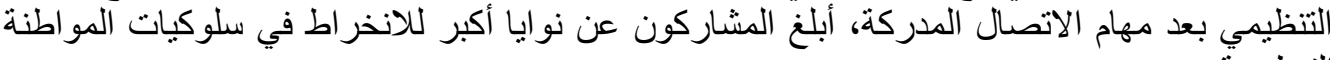
التنظبمية. وفى نفس السياق استهدفت دراسة (Taşkıran et al, 2017) التعرف على إنى دور التمانل التنظيمي كمتغير وسيط في العلاقة بين الإدارة المهنية التنظيمية المدركة على نوايا ترك العمل، وتوصلت الت دور نتائج

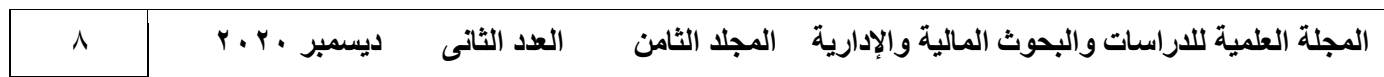


خصائص الهوية التظظيمية وأثرها على التماثل التظظيمى لاى العاملين بثركات قطاع الأعمال العام للغزل والنسيج بوسط الدلتا

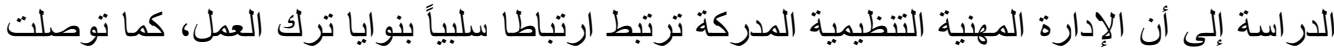
الدراسة إلى وجود أثر معنوي للتماتل التنظيمي في العلاقة بين الإدارة العيط المهنية التنظيمية المدركة ونوايا

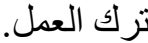

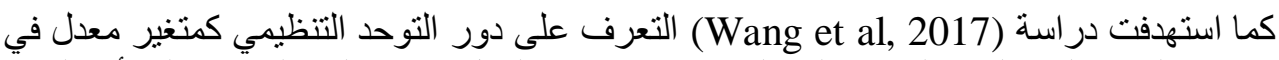

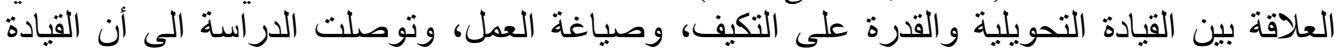

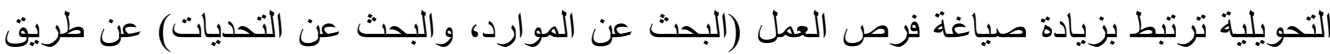

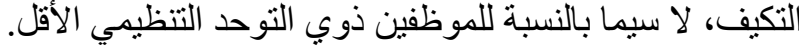

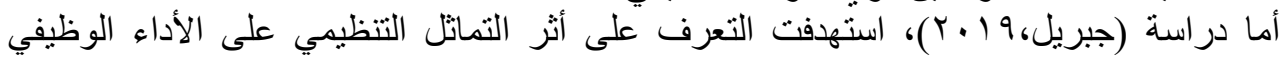

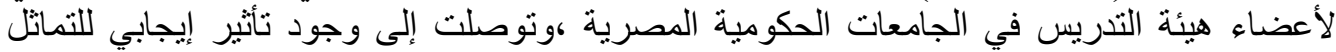

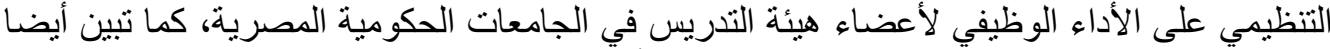

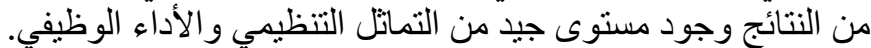

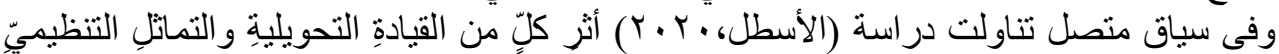

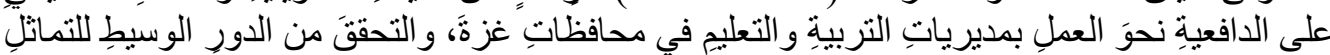

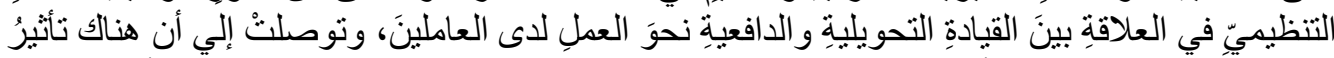

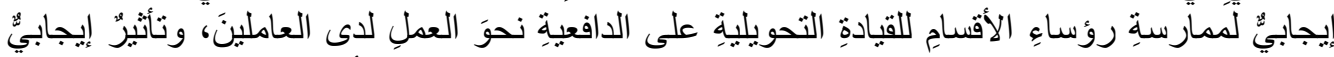

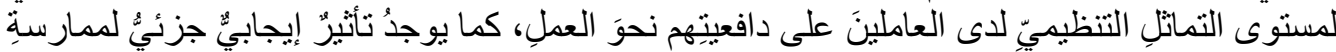

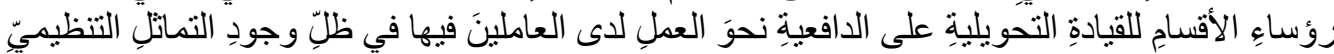

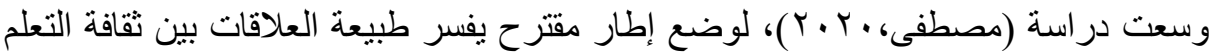
كمتغيرِ وسيط.

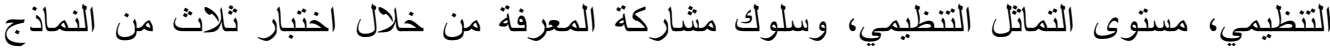

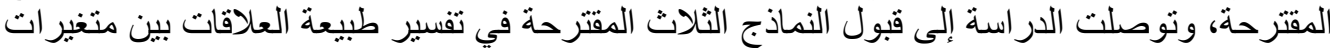

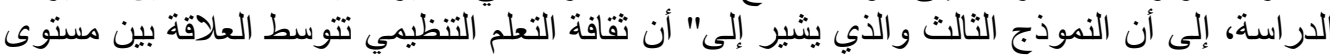

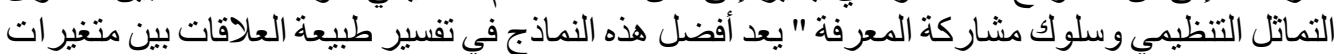

وفي ضوء ما تم عرضه في الإطار النظري والدراسات السابقة، فإن الباحث توصل إلى عده

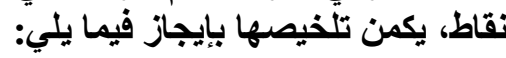

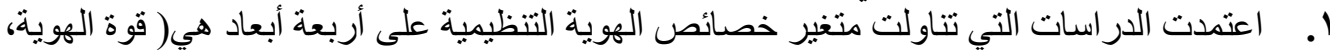
و الهوية المعيارية، والهوية النفعية، و الصورة الذيات التهنية للمنظمة).

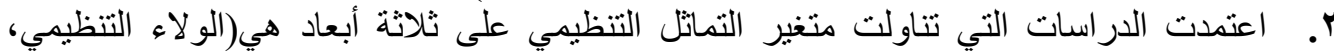
و التشابه، و العضوية).

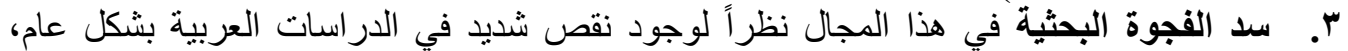

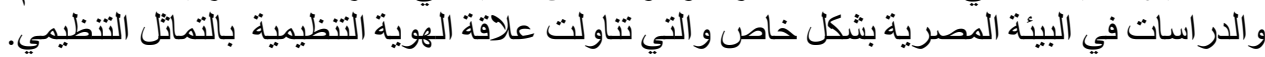

تأتي الأهمية العلمية لهذه الدر اسة من أنها تتناول مفاهيم حديثة نسبياً في أدبيات إدارة الموارد

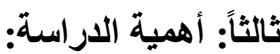

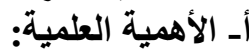

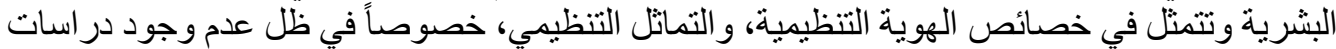
تناولت هذه المفاهيم بالدر اسة و التحليل في نموذج و احد، ومن ثم فإن هذه الدر اسةة تمثل محاولة من الباحث لتأصيل هذه المفاهيم.

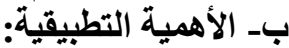
تأتي الأهمية التطبيقية لهذه الدراسة من مساهمة نتائجها في مساعدة مديري إدارة الموارد

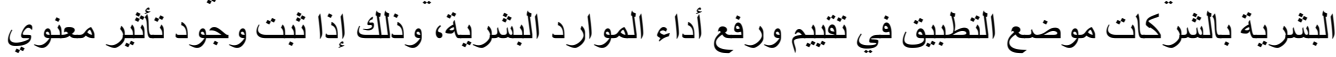
لكل من الهوية التنظيمية والتماتل التنظيمي. فئني

المجلة العلمية للاراسات والبحوث المالية والإدارية المجلد الثامن العدد الثانى


خصائص الهوية التظظيمية وأثرها على التماثل التنظيمى لاى العاملين بثركات قطاع الأعمال العام للغزل والنسبج بوسط الدلتا

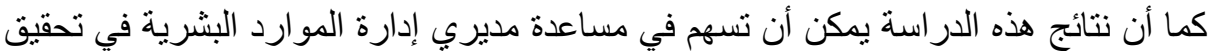

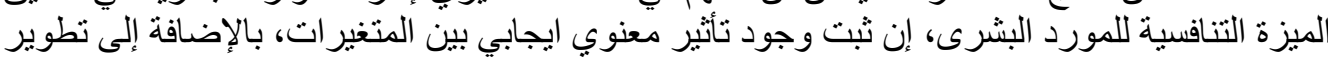

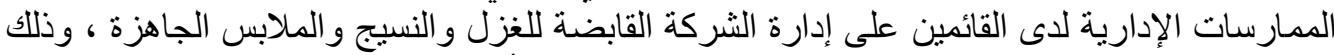

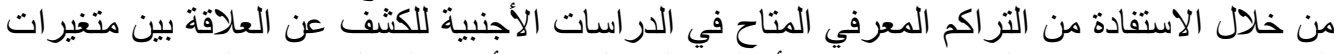

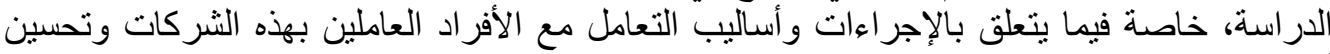

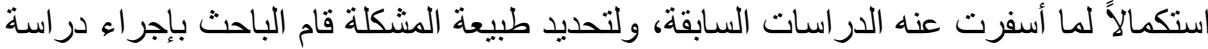

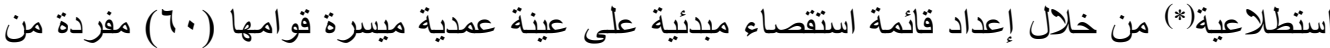

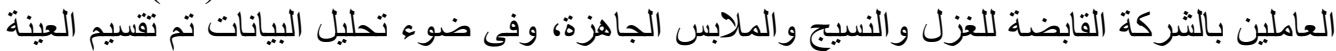

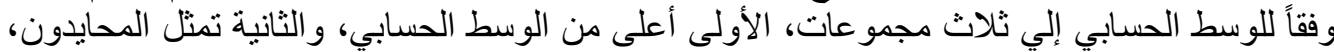

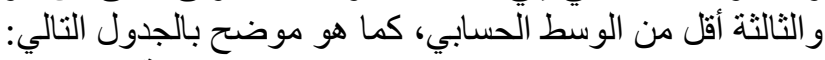

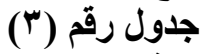

نتائج تحليل بيانات الدراسة الإستطلاعية لمتغير ات الاراسة على أساس الوسط الحسابي

\begin{tabular}{|c|c|c|c|c|c|c|}
\hline \multicolumn{2}{|c|}{ أعلى من الوسط الحسابي } & \multicolumn{2}{|c|}{ المحايدون } & \multicolumn{2}{|c|}{ أقلّ من الوسط } & \multirow{2}{*}{ الأبعاد } \\
\hline النسبة & المفردات & النسبة & المفردات & النسبة & المفردات & \\
\hline$\% r r$ & $1 \varepsilon$ & $\% \mathrm{~V}$ & $\varepsilon$ & $\% v$ & $\varepsilon r$ & الهوية التنظيمية \\
\hline$\% / V$ & 1. & $\% \wedge$ & 0 & $\% \vee 0$ & $\leqslant 0$ & التماثل التنظيمي \\
\hline
\end{tabular}

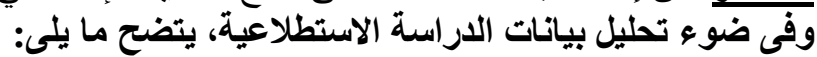

ا.توصل الباحث إلى وجود انخفاض في آر اء مفردات عينة الدراسة فيما يتعلق بأبعاد الهوية التنظيمية

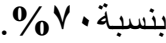

r. توصل الباحث إلى وجود انخفاض في آراء مفردات عينة الدر اسة فيما يتعلق بأبعاد التماتل التنظيمي

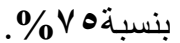

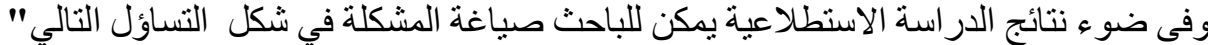

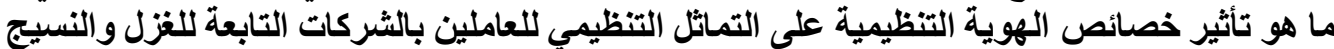

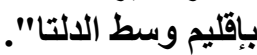

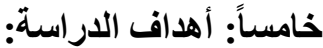

يسعى الباحث في هذه الدراسة لتحقيق الأهداف التالية:

1. تحديد طبيعة العلاقة بين أبعاد الهوية التنظيمية وأبعاد التماثل التنظيمي.

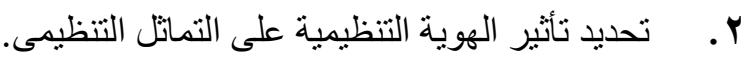

r. تحديد الإختلافات بين آر اء العاملين بالثركات محل الدراسة فيما يتعلق بمتغير ات الدراسة وذلك

باختلاف المتغير ات الديمو غر افية.

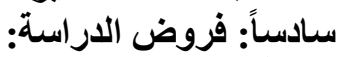

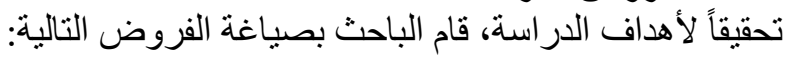

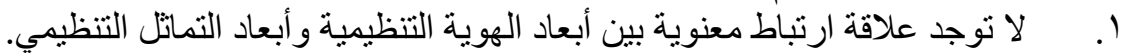

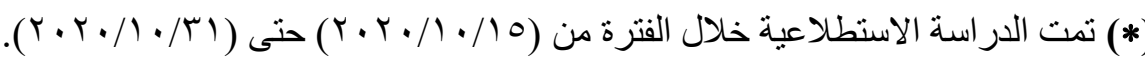

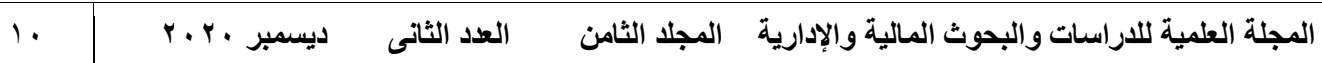


خصائص الهوية التظيمية وأثرها على التماثل التنظيمى لاى العاملين بثركات قطاع الأعمال العام للغزل والنسبج بوسط الدلتا

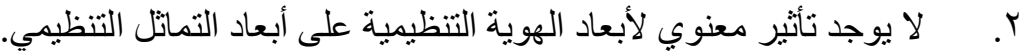

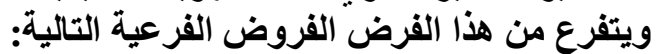

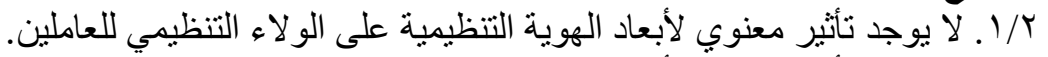

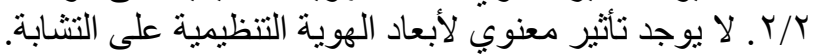

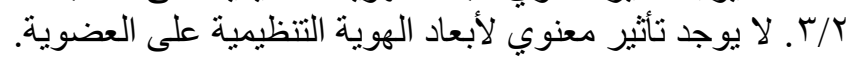

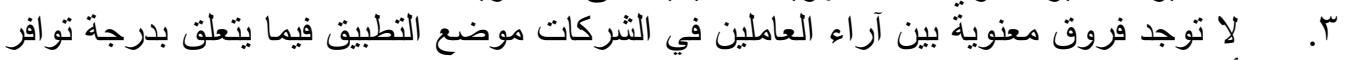
أبعاد الهوية التنظيمية وفقا للنو التوع و والحالة الاجتماعية.

ويتفرع من هذا الفرض الفروض الفروعية التالية:

بآ ألا توجد فروق معنوية بين آراء العاملين في الثركات موضع التطبيق فيما يتعلق بدرجة تو افر

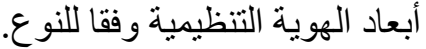

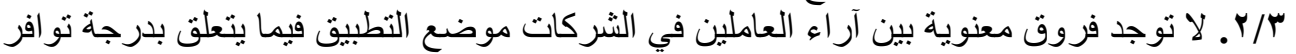

أبعاد الهوية التنظيمية وفقا للحالة الاجتماعية.

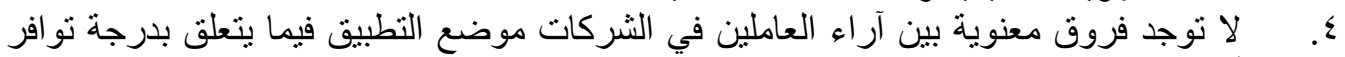

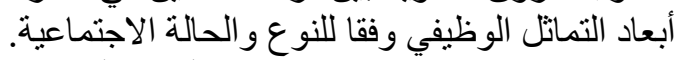

ويتفرع من هذا الفرض الفروض الفرضان الفرعية التالية:

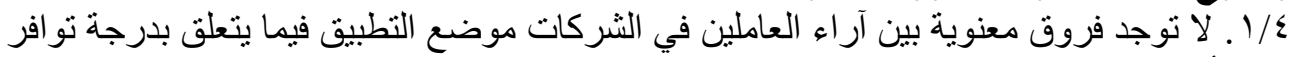

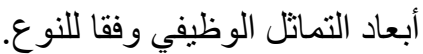

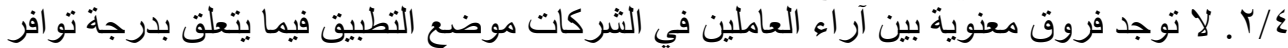

أبعاد التماتل الوظيفي وفقا للحالة الاجتماعية.

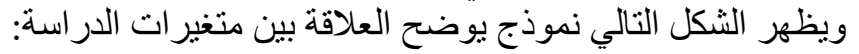

شكل (1)

النموذج المقترح للعلاقة بين متغيرات الدراسة

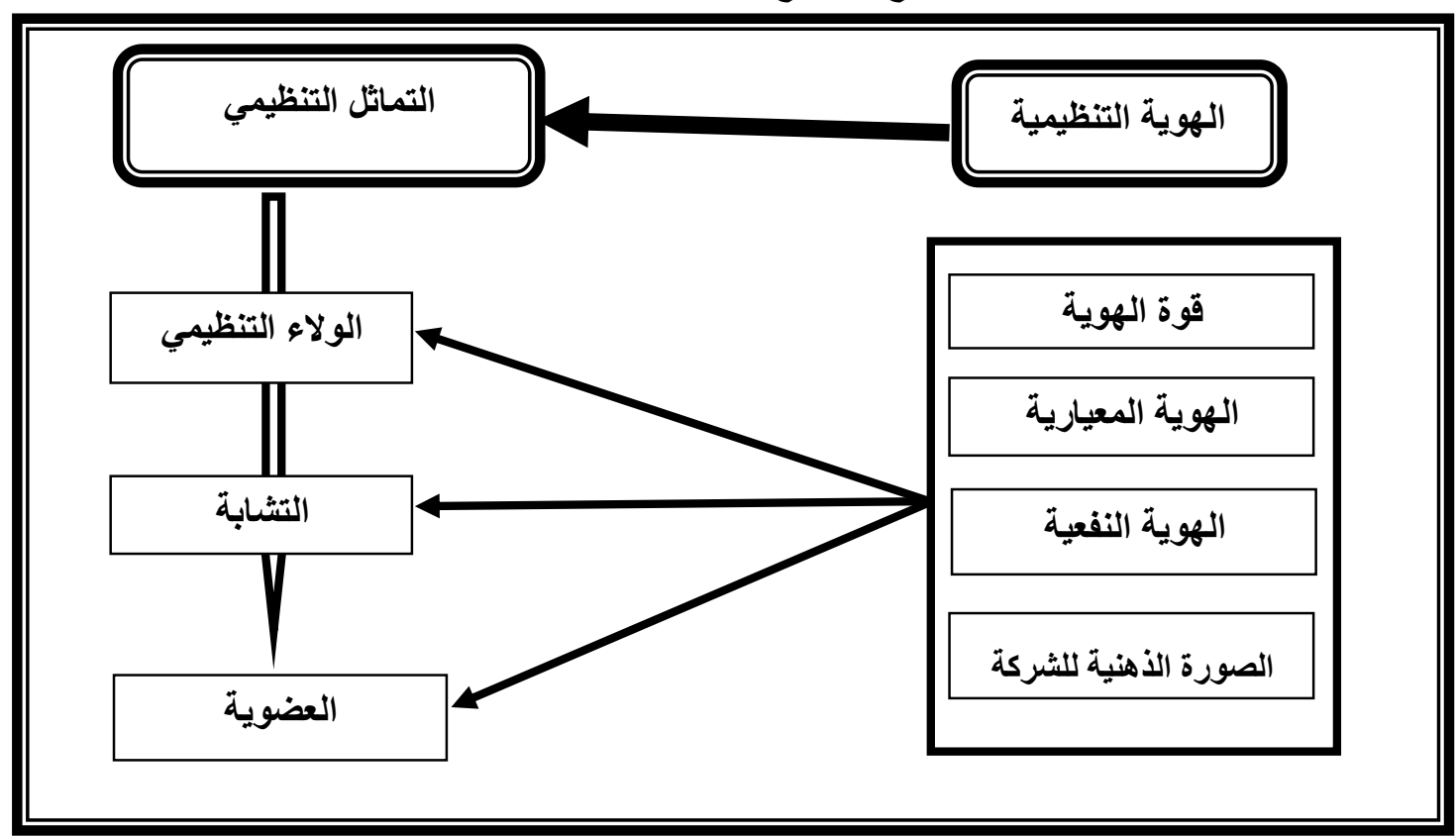

المصدر: من إعداد الباحث

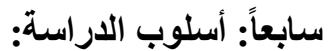

أ) البيانات المطلوبة ومصادر ها: اعنمد الباحث في هذه الدراسة على نوعين من البيانات هما:

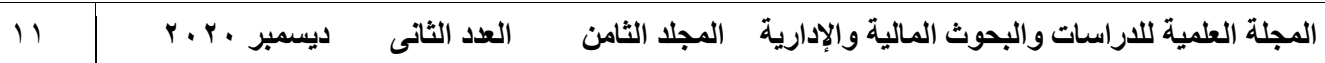


خصائص الهوية التظظيمية وأثرها على التماثل التتظيمى لاى العاملين بثركات قطاع الأعمال العام للغزل و النسيج بوسط الدلتا

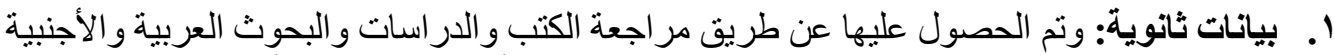

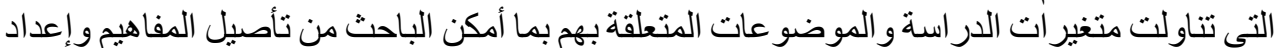

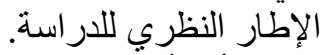

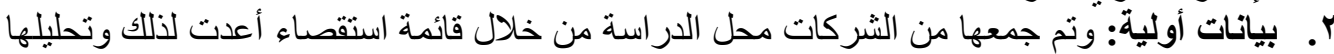

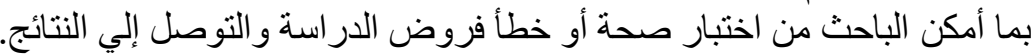

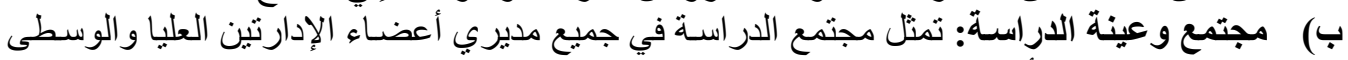

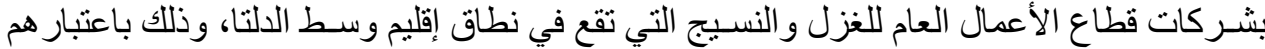

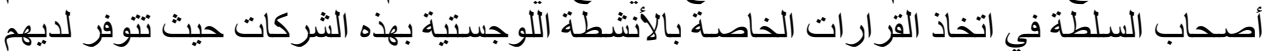

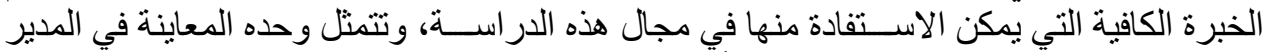

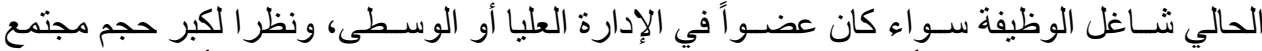

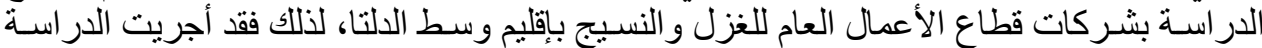

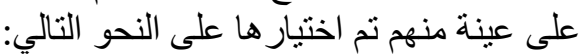

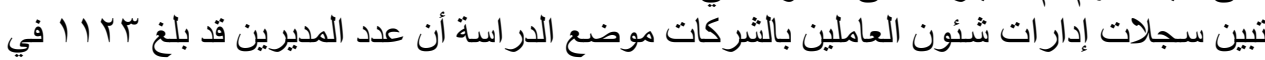

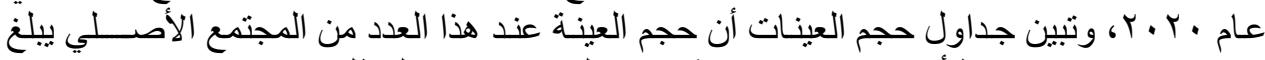

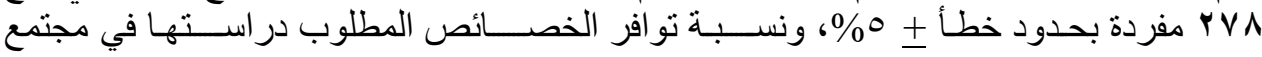

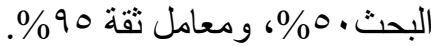

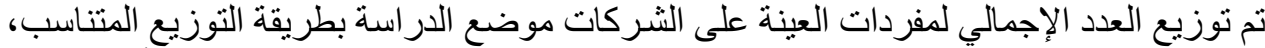

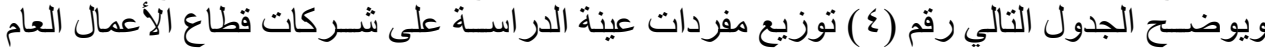

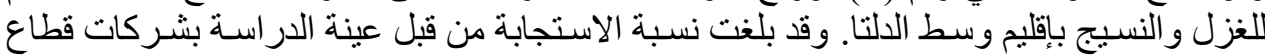

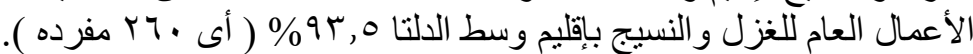

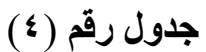

توزيع مفردات عينة الدراسة على شركات قطاع الأعمال العام للغزل والنسيج بإقليم وسط الدلتا

\begin{tabular}{|c|c|c|c|c|}
\hline العينة الع & الأهمية النسبية & العدد & البيـــــان & b \\
\hline YYI & $\cdot, \vee \vee q$ & Aqr & شركة مصر للغزل والنسيج. & 1 \\
\hline YY & $\cdot, \cdot \Lambda$ & 9. & شركة النصر للفزل والنسيج. & $r$ \\
\hline YI & $\cdot, \cdot \wedge$ & 19 & شركة الدلتا للغزل والنسيج. & $\mu$ \\
\hline 12 & $\cdot, \cdot 0$ & Or & شركة الدقهلية للغزل والنسيج. & $\varepsilon$ \\
\hline rVA & $\% 1 \ldots$ & $11 Y \mu$ & الإجمالي & \\
\hline
\end{tabular}

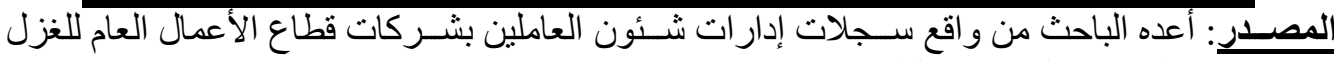

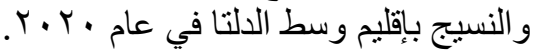

أدوات جمع البيانات الأولية: اعنمد الباحث في تجميع بيانات الدر اسة الميدانية من مصادر ها الأولية

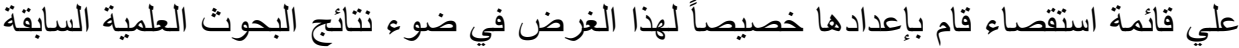

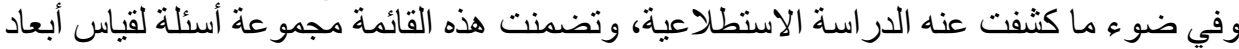
متغيرات الدراسة المتمثلة في كل من الهية الانطية التنظيمية، و التماتل التنظيمي).

$$
\text { قياس متغيرات الدراسة: تحتوى هذه الدراسة على نوعين من المتغير ات هما: }
$$


خصائص الهوية التظظيمية وأثرها على التماثل التظظيمى لاى العاملين بثركات قطاع الأعمال العام للفزل والنسيج بوسط الدلتا

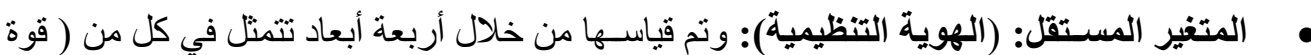

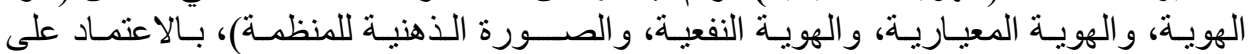

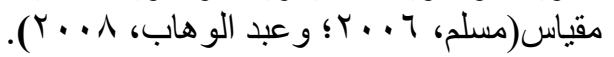

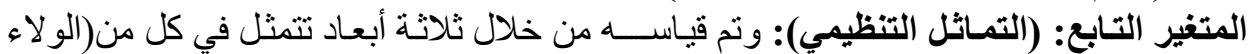

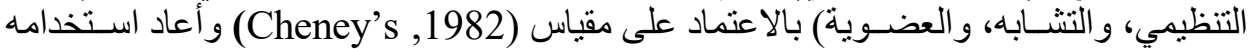

.(Johnson, 1999)

ه) (أساليب التحليل الاحصائي للبيانات: اعتمد الباحث على الأساليب الإحصائية التالية باستخدام برنامج :(SPSS. V. 23)

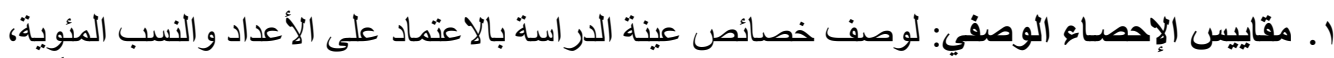

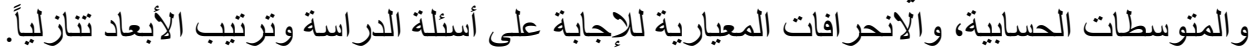

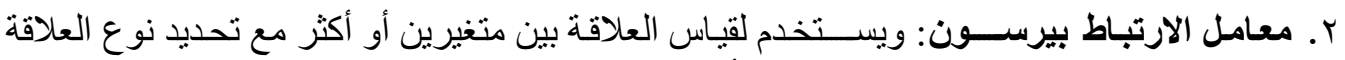

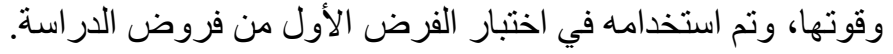

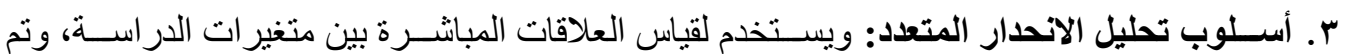

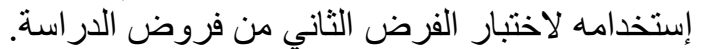

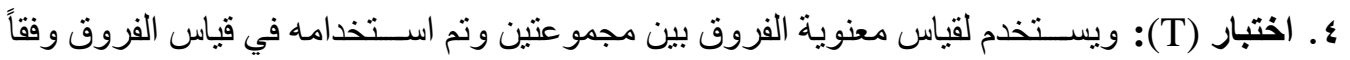

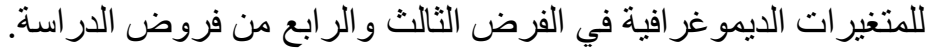

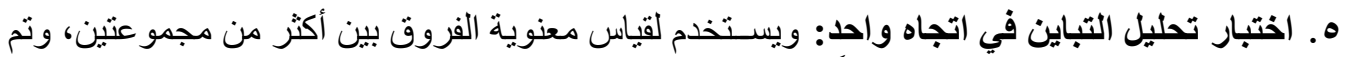

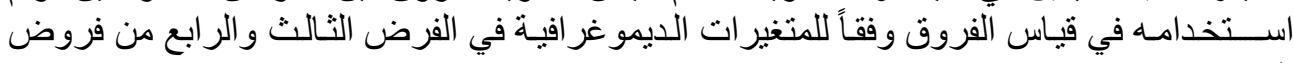
الدراسة.

ثامناً: اختبار الفروض وتحليل النتائج:

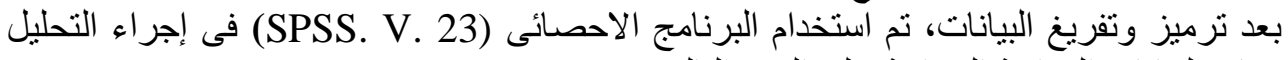

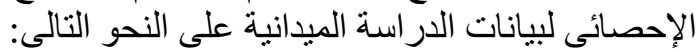

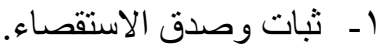
r- ا- التحليل الوصفي لأبعاد الهوية التنظيمية و أبعاد التمانل التنظيمي.

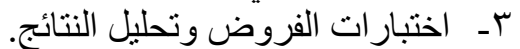

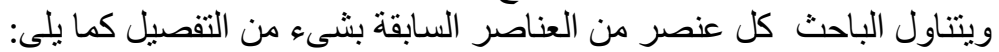

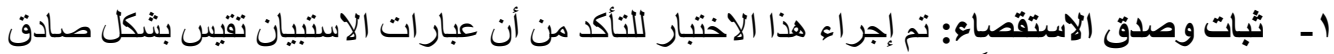

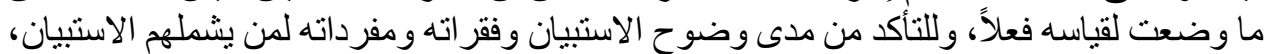

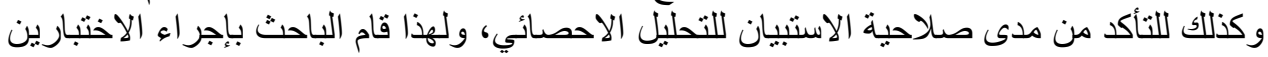

قام الباحث بإجر اء اختبار الصدق الذاتي للتأكد من سلامة العبارات ومدى ملائمتها لقياس المتغير اتي،

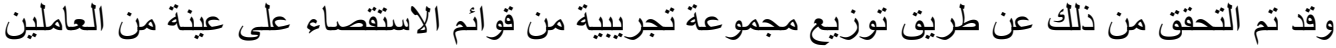

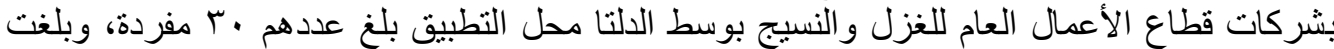

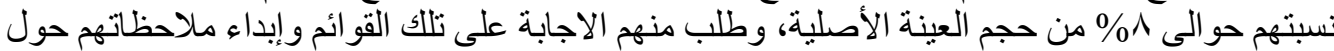

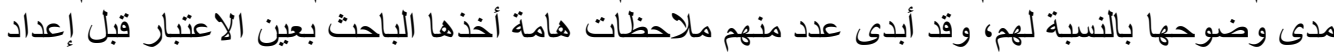

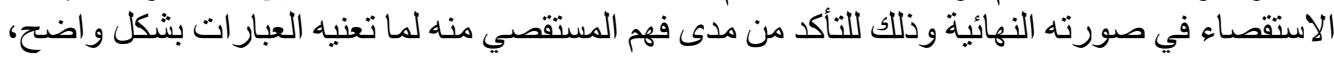

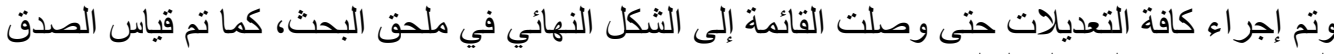

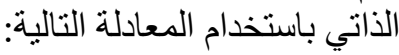

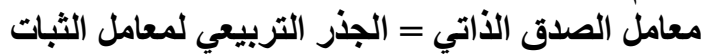

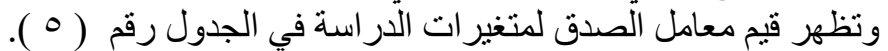

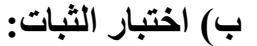

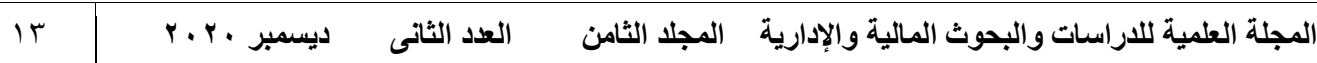


خصائص الهوية التظيمية وأثرها على التماثل التنظيمى لاى العاملين بشركات قطاع الأعمال العام للفزل و النسيج بوسط الدلتا

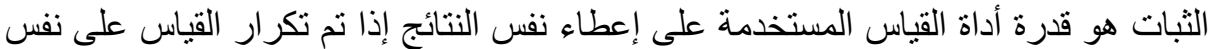

الشخص عدة مرات في نفس الظروف. ولقياس مدى ثبات المقاييس المستخدمة تم استخدام معامل ألفاء

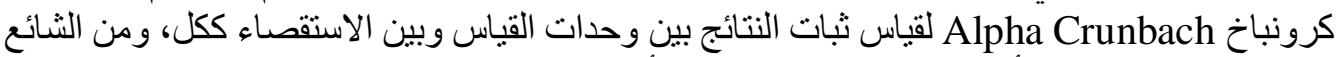

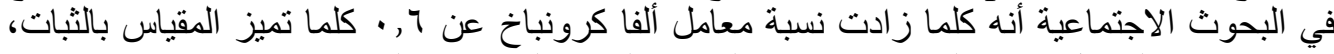

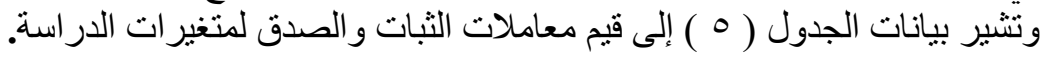

$$
\text { جدول (•) }
$$

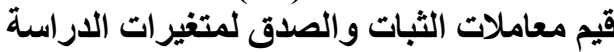

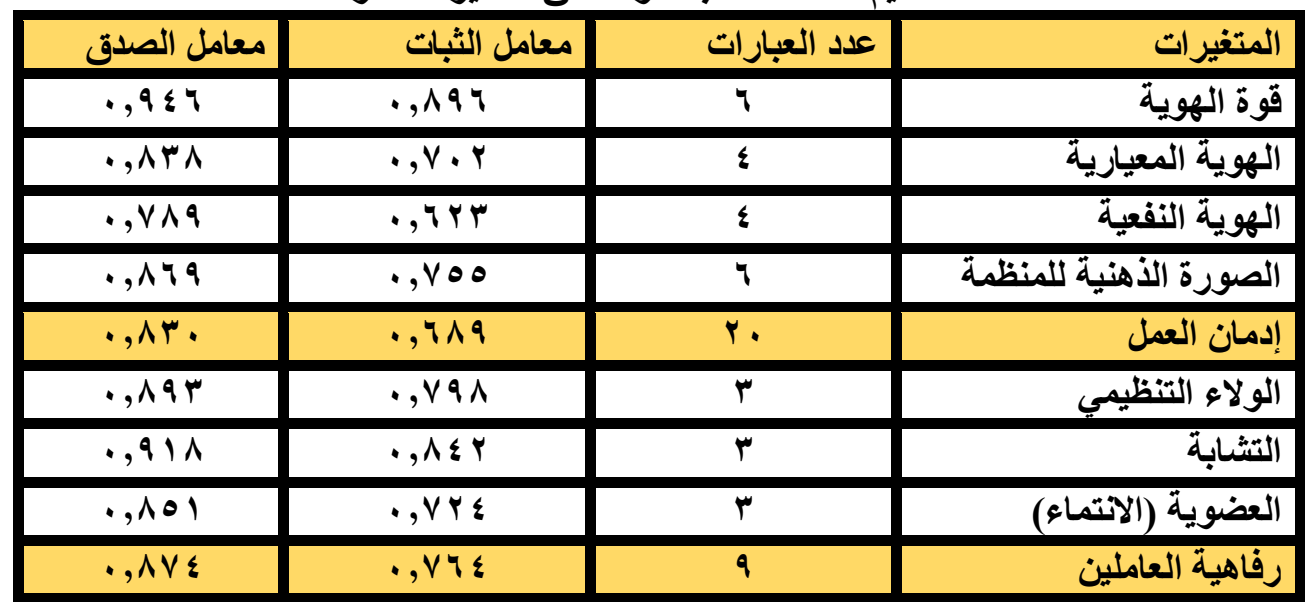

$$
\text { المصدر: من إعداد الباحث اعتماداً على نتائج التحليل الاحصائي }
$$

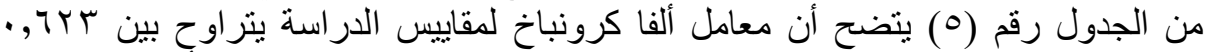

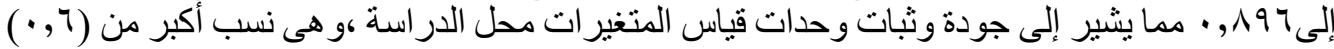

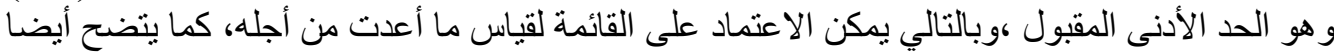

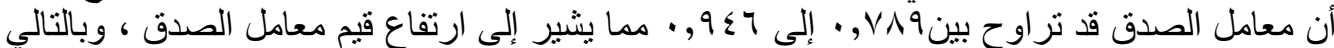

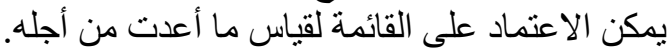

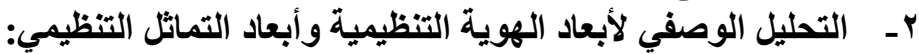

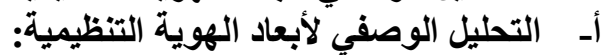

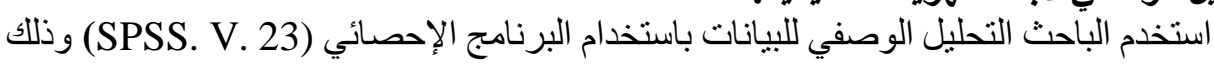

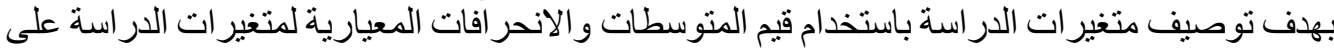

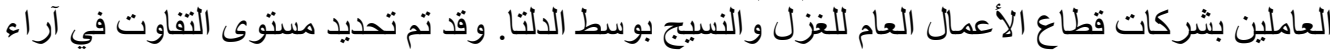
العاملين بالاعتماد على المعادلة الاتية:

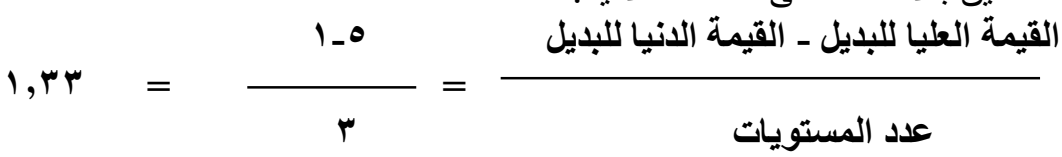

وبذلك بيتر اوح:

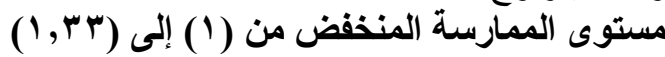

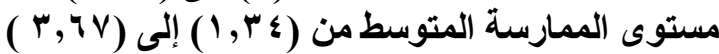

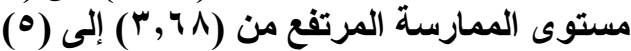

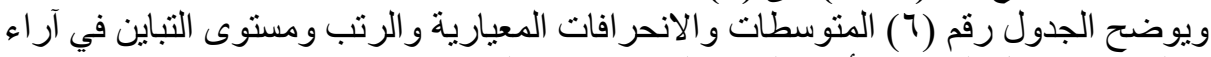

العاملين في الشركات محل الدر اسة لأبعاد الهوية التنظيمية كما يلي: 
خصائص الهوية التظيمية وأثرها على التماثل التنظيمى لاى العاملين بشركات قطاع الأعمال العام للفزل و النسيج بوسط الدلتا

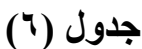

مستوى التباين في آراء العاملين بثركات قطاع الأعمال العام للغزل والنسيج بوسط الدلتا لأبعاد الهوية التظيمية الاعمال العاع

\begin{tabular}{|c|c|c|c|c|c|}
\hline المرتبة & مستوى التباين & المعياري & الحستوسي & أبعاد الهوية التنظيمية & الرقم \\
\hline$r$ & متوسط &.,$\vee \wedge$ & $r, 0 \Lambda$ & قوة الهوية & 1 \\
\hline$r$ & متوسط & $\cdot, 7 \mathrm{~V}$ & $r, I V$ & الهوية المعيارية & $r$ \\
\hline 1 & متوسط &., 00 & $r, \uparrow$ & الهوية النفعية & $r$ \\
\hline$\varepsilon$ & متوسط & . & $r, . q$ & الصورة الذهنية للشركة & $\varepsilon$ \\
\hline & متوسط &., $0 Y$ & $r, \leqslant 0$ & \multicolumn{2}{|c|}{ اللارجة الكلية } \\
\hline
\end{tabular}

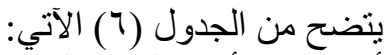

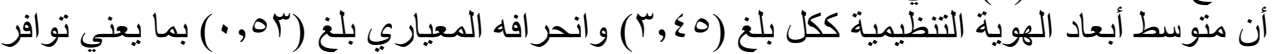

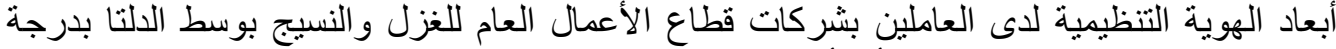
متوسطة، كما اتضح من الجدول أن أبعاد الهوية التتظيمية كانت في المستوى المتوسط، وتراوحت

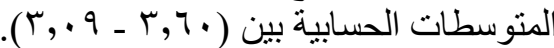

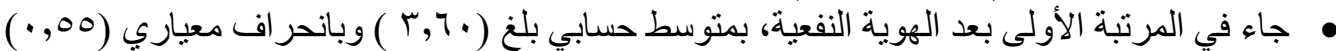
بما يعني وجود اهتمامات للإدارة لتحقيق المكاسب الإقتصنية الإدية وتعظيم الأرباح وتحقيق المصنالح الذاتية

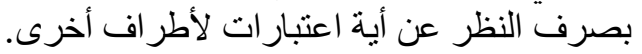

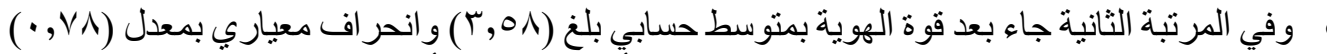

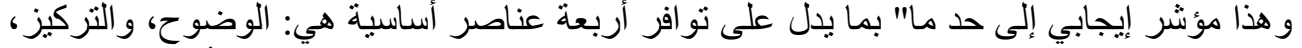

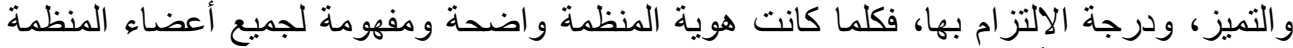

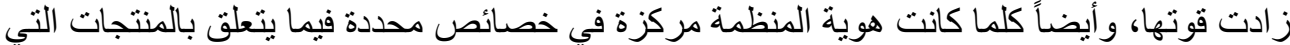

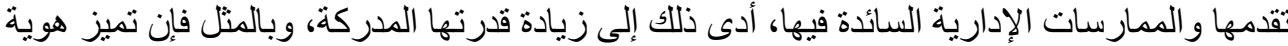

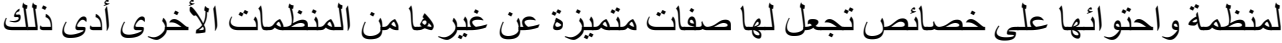

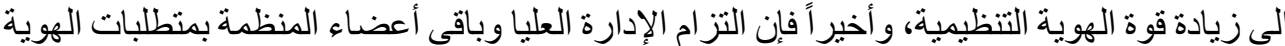

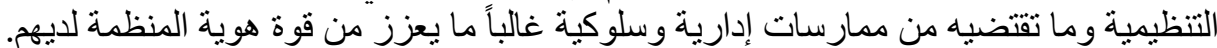

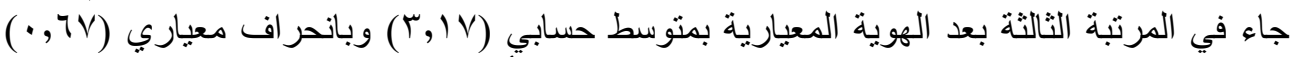

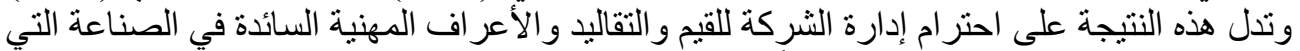

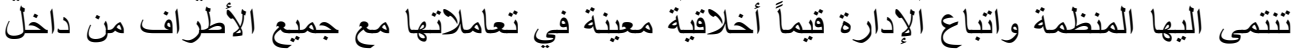

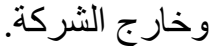

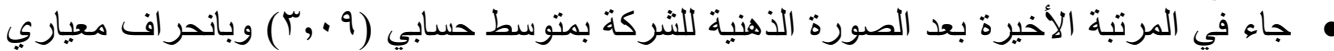
( بآ, • ) وتدل هذه النتيجة على ضعف القوة القدة النسبية لهوية الثركة كما يدركها العاملون بها.

بـ - التحليل الوصفي لأبعاد التماثل التظيمي:

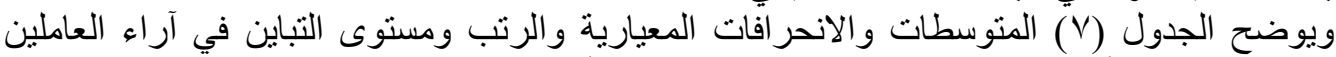

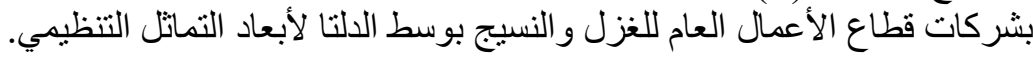


خصائص الهوية التظيمية وأثرها على التماثل التظظيمى لاى العاملين بثركات قطاع الأعمال العام للفزل و النسيج بوسط الدلتا

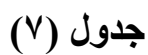

مستوى التباين في آراء العاملين بثركات قطاع الأعمال العام للغزل والنسيج بوسط الالتا لأبعاد

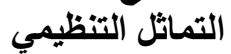

المصدر: من إعداد الباحث اعتمادا على نتائج التحليل الاحصائي

\begin{tabular}{|c|c|c|c|c|c|}
\hline المرتبة & التباينوى & الالتحرياري & الحستوسطي & أبعاد التماثل التظظيمي & الرقم الرق \\
\hline$r$ & مرتفع & $\cdot, 71$ & $T, V T$ & الو لاء التنظيمى & 1 \\
\hline$r$ & مرتفع & $\cdot, \nabla \Gamma$ & $r, \Lambda Y$ & التشابة & $r$ \\
\hline 1 & مرتفع &., 01 & $r, \wedge q$ & الإنتماء (العضوية) & $r$ \\
\hline & مرتفع &., 00 & $r, \wedge 1$ & الدرجة الكلية & \\
\hline
\end{tabular}

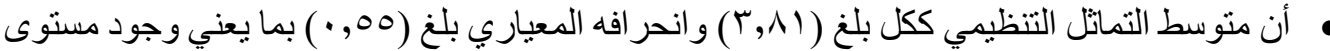

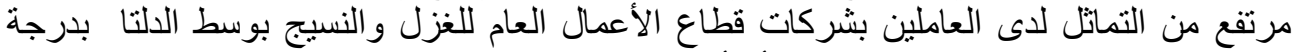

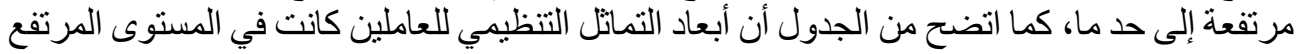

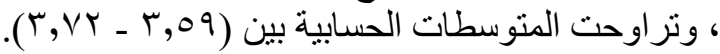

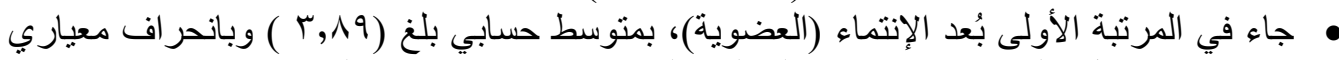

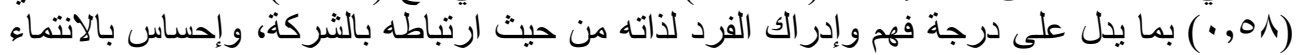

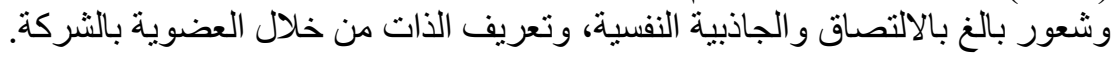

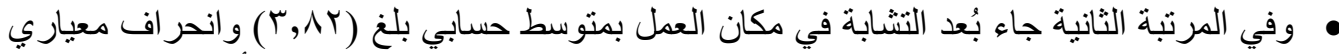

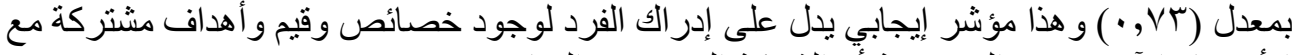

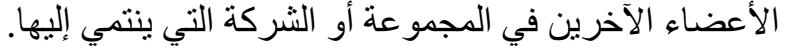

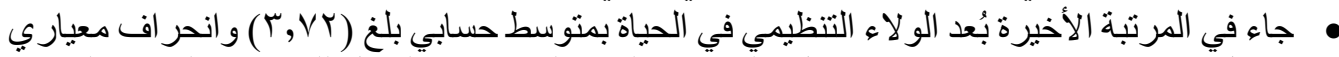

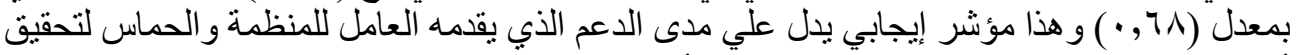

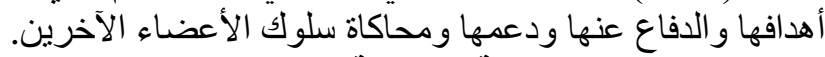

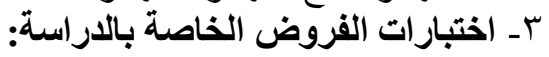

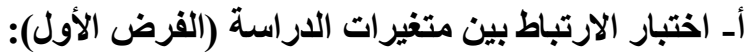

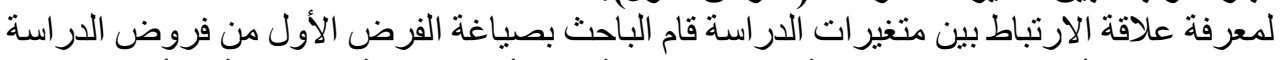

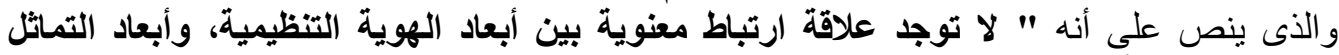

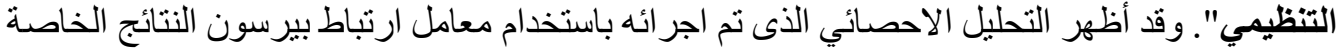

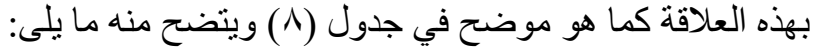

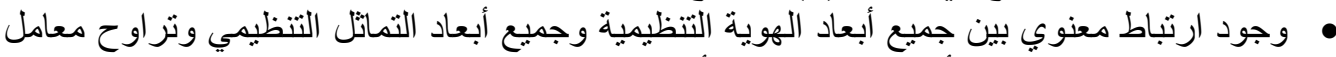

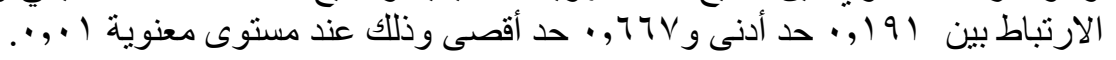
• أن أقوى علاقة ارتباط كانت بين بُعد قوة الهوية (الهوية التنظيمية) وبعد التشابة (التماتل التنظيمي)

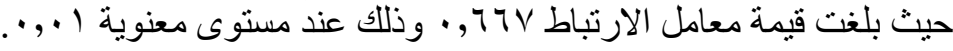

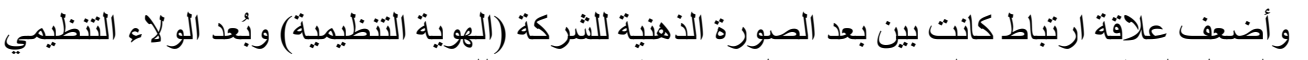

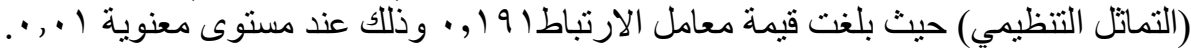

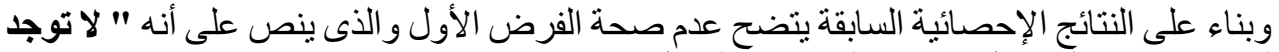
علاقة ارتباط معنوية بين أبعاد الهوية التنظيمية، وأبعاد التماثل التنظيمي". 
خصائص الهوية التظظية و أثرها على التماتثل التنظيمى لاى العاملين بثركات قطاع الأعمال العام للغزل والنسبج بوسط الدلتا

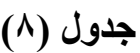

مصفوفة معاملات الارتباط بين متغيرات الدراسة

\begin{tabular}{|c|c|c|c|c|c|c|c|}
\hline (العضوية & التشابة & التظظيمي & اللشركةة & النفعية & المهيارية & قوة الهوية & المتغيرات \\
\hline & & & & & & 1 & قوة الهوية \\
\hline & & & & & 1 & ${ }^{* *},, \leq 71$ & الهوية المعيارية \\
\hline & & & & 1 & ${ }^{* *},, \Sigma T r$ & **., & الهوية النفعية \\
\hline & & & 1 & $* *, 0.0$ & **., 077 & **, , 707 & الصورة الذهنية للشركة \\
\hline & & 1 & $* * ., 191$ & ${ }^{* *} \cdot, 0 \leq 0$ & **., rr. & $* *,,\{\cdot 1$ & الولاء التنظيمي \\
\hline & 1 & ${ }^{* *},, 0 \leqslant V$ & ${ }^{* *} \cdot, r \vee r$ & ${ }^{* *},, \leq \vee \curlyvee$ & ${ }^{* *} \cdot, r \wedge r$ & **, , TาV & التشابة \\
\hline 1 & **., Or & $* *,, \leq 91$ & $\cdot, \pi)$ & $* *, 01 \pi$ & **., & ${ }^{* *},, \mu \vee \mu$ & العضوية (الإنتماء) \\
\hline
\end{tabular}

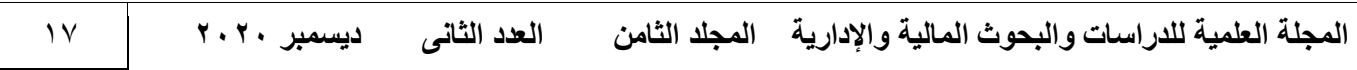


خصائص الهوية التظيمية وأثرها على التماثل التظظيمي لاى العاملين بشركات قطاع الأعمال العام للغزل والنسيج بوسط الدلتا

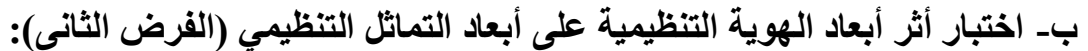

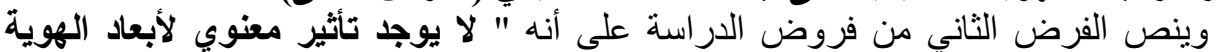

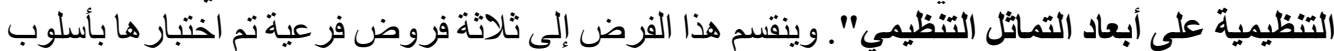

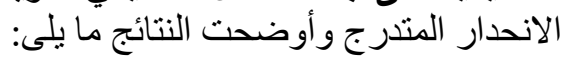

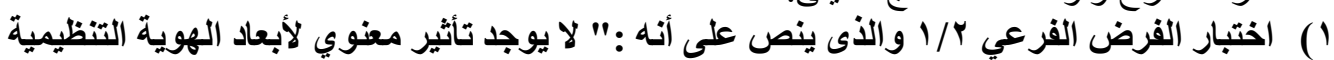

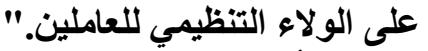

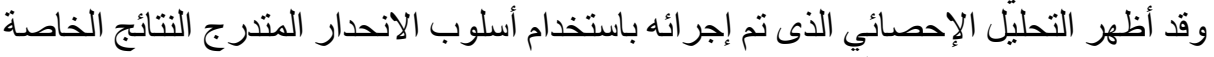

بهذه العلاقة كما هو موضح في جدول (9) الأحئ

جاول (9) (9) (9)

معاملات الانحدار المتارج لتأثير أبعاد الهوية التنظيمية على الولاء التنظيمي للعاملين

\begin{tabular}{|c|c|c|c|c|}
\hline \multirow{2}{*}{ الترتيب } & \multicolumn{3}{|c|}{ Stepwise Regression } & \multirow{2}{*}{ المستغيرلة } \\
\hline & Sig. & $\mathbf{T}$ & Beta. & \\
\hline لأول & $* *,, \ldots$ & $\lambda, r_{0}$ & $\cdot, \leqslant \cdot 1$ & قوة الهوية \\
\hline & & - & - & الهوية المعيارية \\
\hline & & - & - & الهوية النفعية \\
\hline & & - & - & الصورة الذهنية للشركة \\
\hline & & & $79, \pi 1$. & $\mathbf{F}$ \\
\hline & & & $* *,, \ldots$ & Sig. \\
\hline & & &., 171 & R2 \\
\hline
\end{tabular}

المصدر: من إعداد الباحث إعتماداً على نتائج التحليل الإحصائي

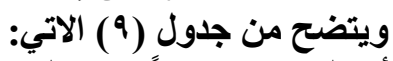

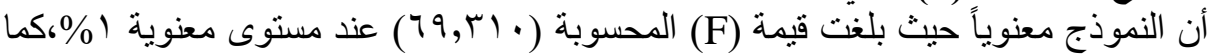

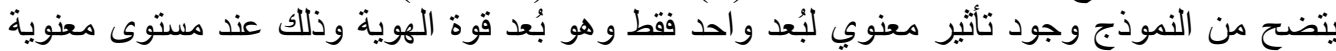

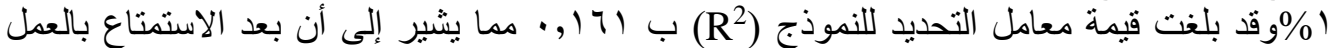

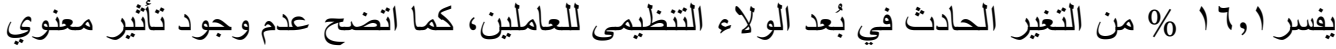

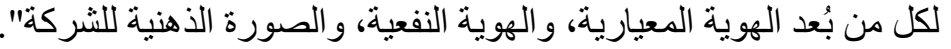

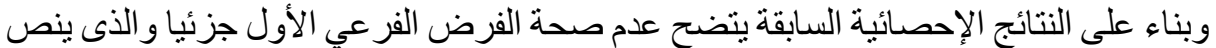

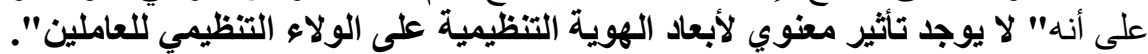

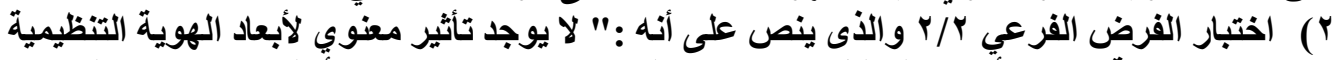

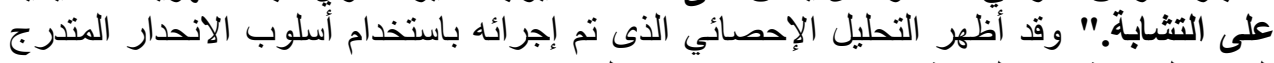

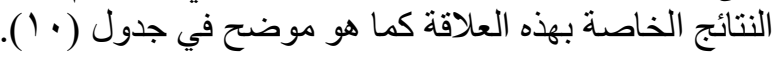

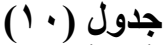

معاملات الانحدار المتدرج لتأثير أبعاد الهوية التنظيمية علي التثابة

\begin{tabular}{|c|c|c|c|c|}
\hline \multirow{2}{*}{ الترتيب } & \multicolumn{3}{|c|}{ Stepwise Regression } & \multirow{2}{*}{ المستفيرة } \\
\hline & Sig. & $\mathbf{T}$ & Beta. & \\
\hline الأول & $* *_{,}, \ldots$ & $1 \varepsilon, \wedge \wedge \mathrm{V}$ &., $0 \vee T$ & قوة الهوية \\
\hline - & - & - & - & الهوية المعيارية \\
\hline 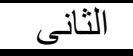 & . & $\Gamma, \wedge \Sigma 1$ &,$r \cdot \Lambda$ & 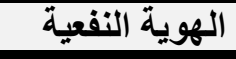 \\
\hline
\end{tabular}

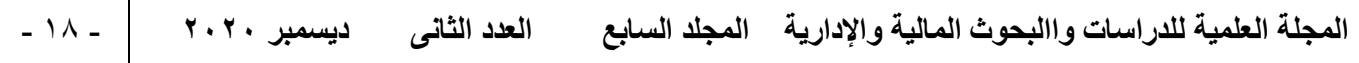


خصائص الهوية التظيمية و أثرها على التماثل التنظيمى لدى العاملين بشركات قطاع الأعمال العام للفزل والنسبج بوسط الدلتا

\begin{tabular}{|c|c|c|c|c|}
\hline \multirow{2}{*}{ الترتيب } & \multicolumn{3}{|c|}{ Stepwise Regression } & \multirow{2}{*}{ لمستغيرة } \\
\hline & Sig. & $\mathbf{T}$ & Beta. & \\
\hline \multirow[t]{4}{*}{-} & - & & & الصورة الأهنية للشركة \\
\hline & \multicolumn{3}{|c|}{$10 V, \varepsilon 1 \mathrm{r}$} & $\mathbf{F}$ \\
\hline & \multicolumn{3}{|c|}{$* *,, \ldots$} & Sig. \\
\hline & \multicolumn{3}{|c|}{$\cdot, \Sigma T V$} & $\mathbf{R 2}$ \\
\hline
\end{tabular}

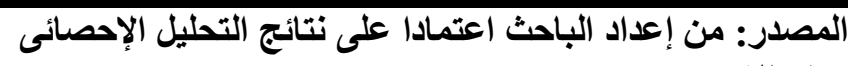

$$
\text { ويتضح من جذول (· (1) الاتي: }
$$

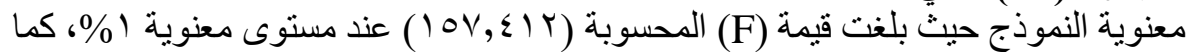

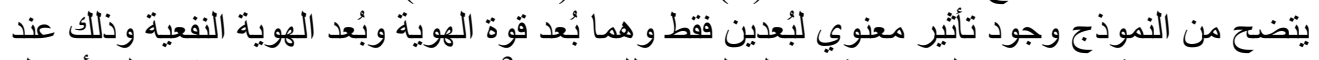

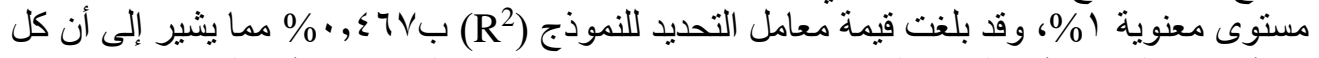

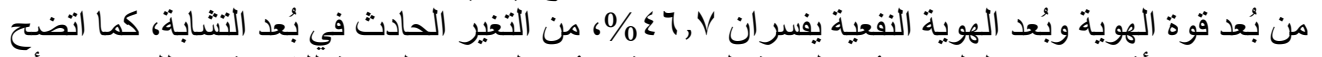

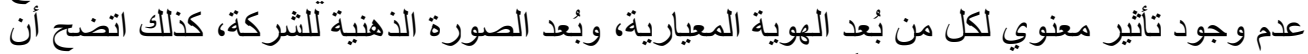

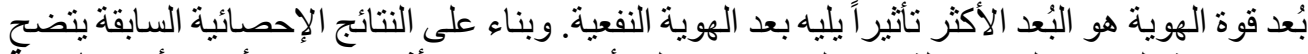

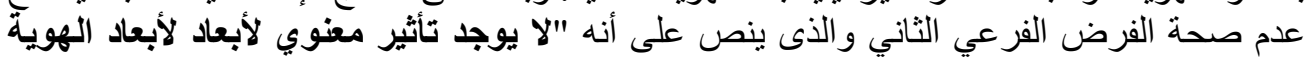
التنظيمية على التثابه".

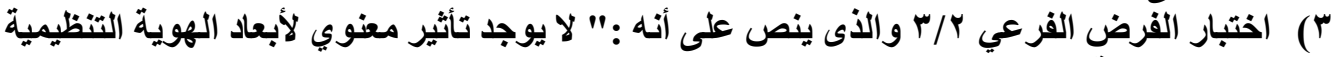

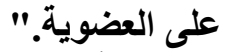
وقد أظهر التحليل الإحصائي الذى تم إجر ائه باستخدام أسلوب الانحدار المتدرج النتائج الخاصة

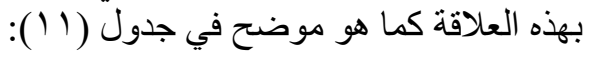

جدول (11) (1) (1)

معاملات الانحدار المتدرج لتأثير أبعاد الهوية التظظيمية على العضوية (الإنتماء)

\begin{tabular}{|c|c|c|c|c|}
\hline \multirow{2}{*}{ الترتيب } & \multicolumn{3}{|c|}{ Stepwise Regression } & \multirow{2}{*}{ المستقيلة } \\
\hline & Sig. & $\mathbf{T}$ & Beta. & \\
\hline الأول & $* *_{.}, \ldots$ & $\varepsilon, \vee \cdot 1$ &., 19. & قوة الهوية \\
\hline الثالث & $* *_{,}, \ldots v$ & $r, \leq \leqslant 7$ &., $1 \times 0$ & الهوية المعيارية \\
\hline 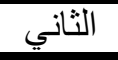 & $* *_{.}, \ldots \wedge$ & T,TVV &., $10 \mathrm{~V}$ & الهوية النفعية \\
\hline \multirow[t]{4}{*}{ 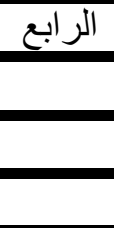 } & $* *_{.}, \ldots r$ & T,707 &., $1 \leq 0$ & الصورة الأهنية للشركة \\
\hline & & & $r \wedge, \cdot r)$ & $\mathbf{F}$ \\
\hline & & & $* *,, \ldots$ & Sig. \\
\hline & & &., 19 & $\mathbf{R 2}$ \\
\hline
\end{tabular}

المصدر: من إعداد الباحث اعتمادا على نتائج التحليل الإحصائي

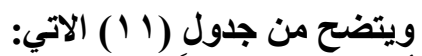

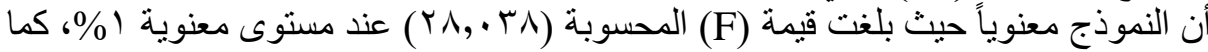

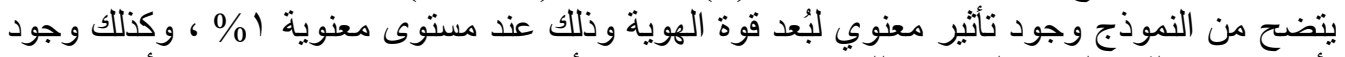

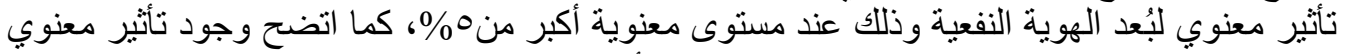

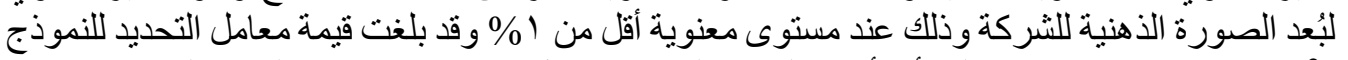
ب 9 (R²)

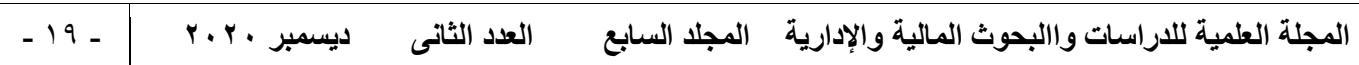


خصائص الهوية التظظيمية و أثرها على التماثل التنظيمى لدى العاملين بشركات قطاع الأعمال العام للفزل والنسبج بوسط الدلتا

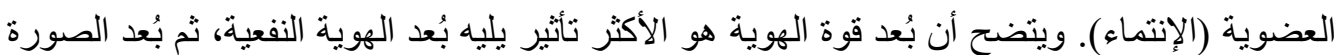

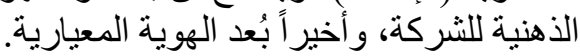

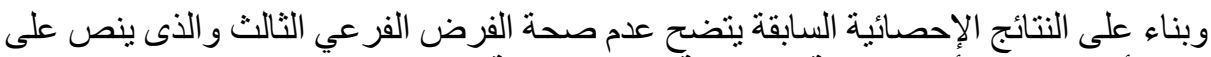

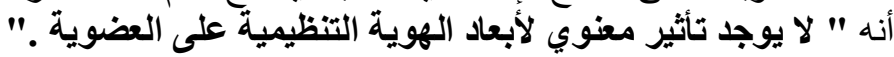

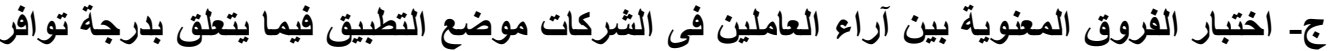

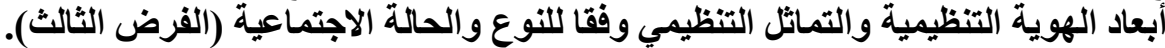

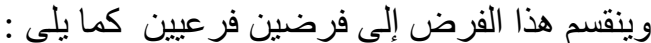
ا - الفرض الفرعي (T/1/) لا توجد فروق معنوية بين آراء العاملين في الثركات موضع التطبيق

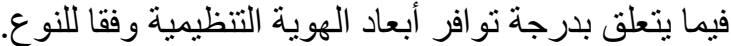

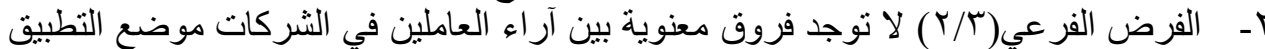

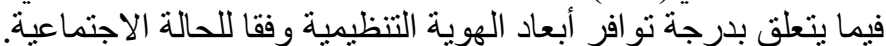

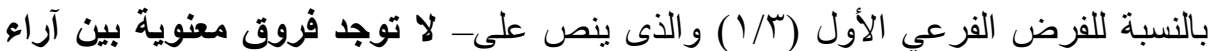

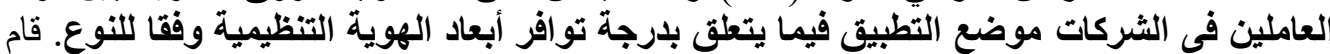

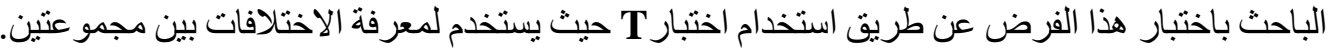
و أظهرت نتائج التحليل الاحصائي الخاصة بذهذا الفرض كما هو موضح بالجدول (r I I). جدول (1) (1) تتائج اختبار T لمعرفة أثر النوع على أبعاد الهوية التنظيمية

\begin{tabular}{|c|c|c|c|c|c|c|}
\hline معنوية & $\mathbf{T}$ & الانـحراف & المتوسط الحسبي & العدد & الجنس & المتغيرات \\
\hline \multirow{2}{*}{., $7 \bullet \wedge$} & \multirow{2}{*}{$\cdot, \leq \leq \mu_{-}$} & $\cdot, \vee \vee q$ & $r, 00$ & $r .0$ & ذكور & \multirow{2}{*}{ قوة الهوية } \\
\hline & & $\cdot, \vee \wedge$ & $p, 0 q$ & or & انـاث & \\
\hline \multirow{2}{*}{., $7 \wedge V$} & \multirow{2}{*}{$\cdot, \varepsilon \cdot \varepsilon=$} & $\cdot, 7 \wedge$ & $r, 10$ & $r .0$ & ذكور & \multirow{2}{*}{ المهوية } \\
\hline & &., $7 V$ & $\overline{\Gamma, 1 \Lambda}$ & Or & انـاث & \\
\hline \multirow{2}{*}{., $99 \varepsilon$} & \multirow{2}{*}{$1,7 \wedge 1$ - } & $\cdot, O Y$ & $r, \otimes r$ & $r .0$ & ذكور & \multirow{2}{*}{ الهوية النفعية } \\
\hline & &., 07 & $r, \bar{\mu}$ & Or & انـاث & \\
\hline \multirow{2}{*}{., .99} & \multirow{2}{*}{$\cdot, \varepsilon \leq 7$. } &., $1 \vee 7$ & r, & $r .0$ & ذكور & \multirow{2}{*}{ الأهنية للشركة } \\
\hline & &., 79 & $r, 0 \varepsilon$ & or & انـاث & \\
\hline
\end{tabular}

المصدر: من إعداد الباحث اعتمادا على التحليل الإحصائي

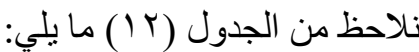

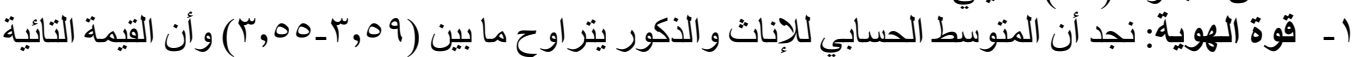

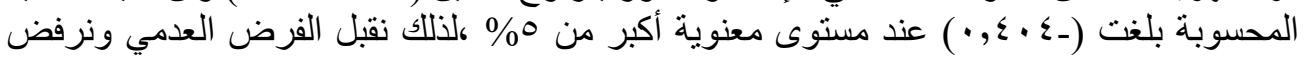
الفرض البديل.

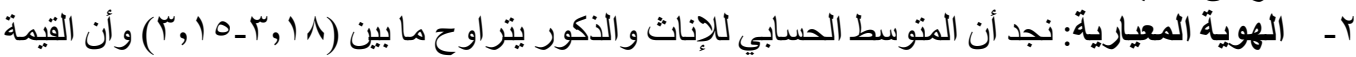

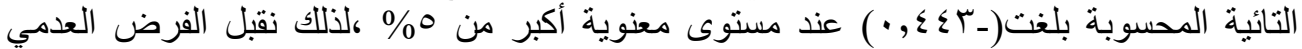
ونرفض الفرض البديل.

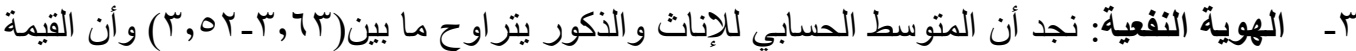

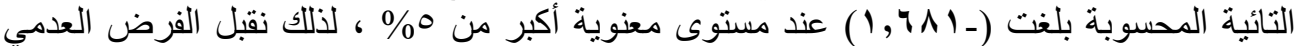
ونرفض الفرض البديل.

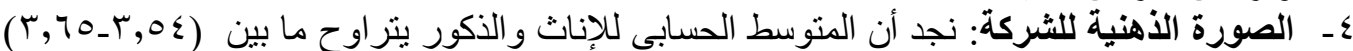

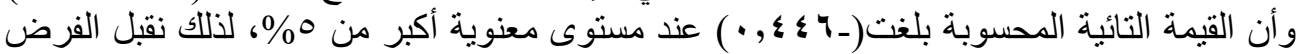
العدمي ونرفض الفرض البديل.

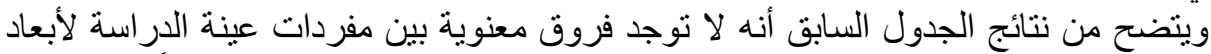

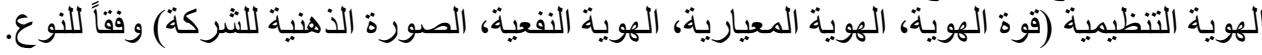

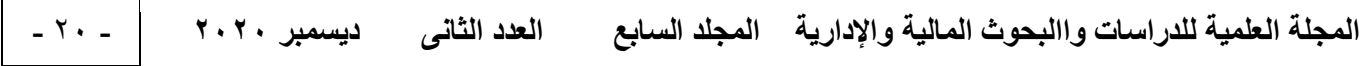


خصائص الهوية التظيمية وأثرها على التماثل التنظيمى لدى العاملين بثركات قطاع الأعمال العام للغزل والنسيج بوسط الدلتا

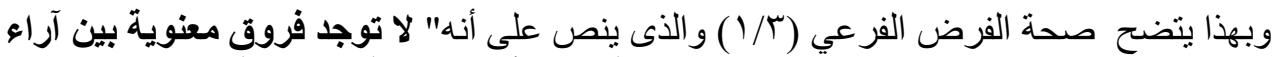

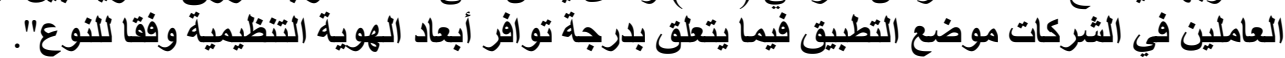

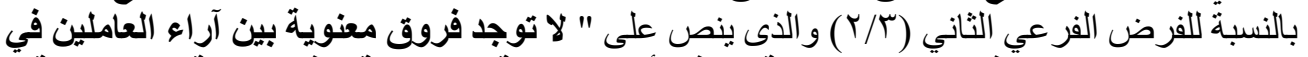

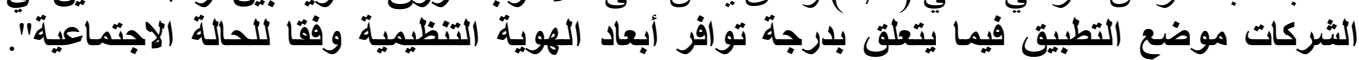

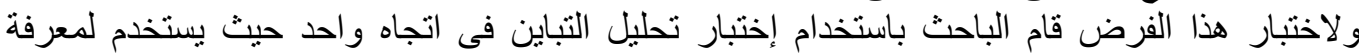
الاختلافات بين أكثر من مجموعنين وأظهر التحليل الإحصائي النتائج الخاصة فهذا الفرض فئ كما هو موضح

في الجدول (1) - (1).

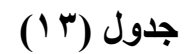

نتائج اختبار التباين في اتجاه واحد لمعرفة أثر الحالة الاجتماعية على أبعاد الهوية التظظيمية

\begin{tabular}{|c|c|c|c|c|c|c|}
\hline معنوية & $\mathbf{F}$ & الانحرافي المعياري & المستوسط المبي & العدد & الحالة الاجتماعيا & المتغير ات \\
\hline \multirow{4}{*}{$\cdot, \cdots$} & \multirow{4}{*}{$v, 117$} & $\cdot, \vee q$ & $r, Y \varepsilon$ & 10 & أعزب & \multirow{4}{*}{ قوة الهوية } \\
\hline & & $\cdot, V_{1}$ & $r, 0$ & $\Delta V$ & متزوج & \\
\hline & & $\cdot, \mathrm{V} \vee$ & $r, v i$ & 187 & متزوج ويعول & \\
\hline & & $\cdot, \wedge 1$ & $r, q$. & 1. & أخرى & \\
\hline \multirow{4}{*}{$\cdot, \cdots$} & \multirow{4}{*}{$7,09 \leq$} &., 71 & $7, q q$ & 10 & أعزب & \multirow{4}{*}{ لهوية المعيارية } \\
\hline & &., 77 & $r, \cdot v$ & $0 V$ & متزوج & \\
\hline & &., $7 \wedge$ & r,Yq & 187 & متزوج ويعول & \\
\hline & & $\cdot, 0 \wedge$ & $r, v V$ & $1 \cdot$ & أخرى & \\
\hline \multirow{4}{*}{$\bullet, \cdots$} & \multirow{4}{*}{9,11 . } & $\cdot, 01$ & $r, \& Y$ & 10 & أعزب & \multirow{4}{*}{ الهوية النفعية } \\
\hline & & $\because, O Y$ & $r, 00$ & $\Delta V$ & متزوج & \\
\hline & &., 00 & $r, 70$ & 187 & متزوج ويعول & \\
\hline & &., 00 & $\varepsilon, Y V$ & 1. & أخرى & \\
\hline \multirow{4}{*}{$\cdot, \cdot r$} & \multirow{4}{*}{7,707} & $\cdot, \wedge 0$ & $r, \wedge v$ & 10 & أعزب & \multirow{4}{*}{ الصورة الذهنية } \\
\hline & &., $7 \mathrm{~V}$ & $r, \wedge q$ & $\Delta V$ & متزوج & \\
\hline & & $\cdot, 7 \mathrm{~V}$ & $r, \vee \wedge$ & 187 & متزوج ويعول & \\
\hline & &., 09 & $r, 7 v$ & 1. & أخرى & \\
\hline
\end{tabular}

المصدر من إعداد الباحث إعتماد على نتائج التحليل الإحصائي

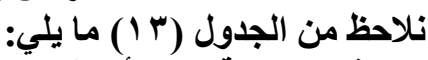

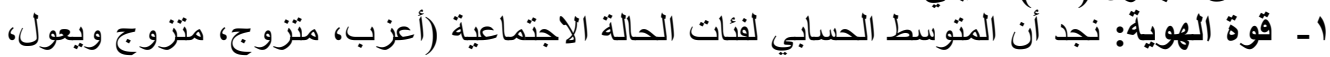

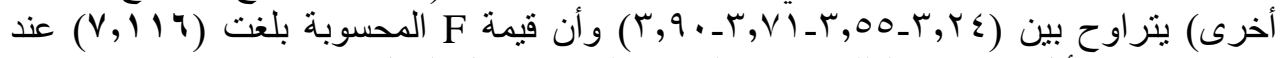

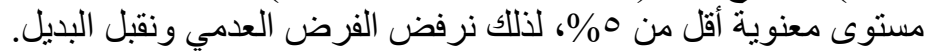

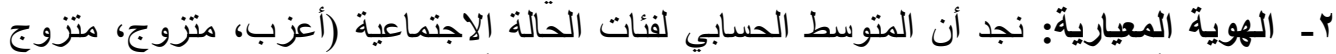

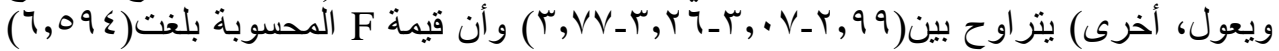

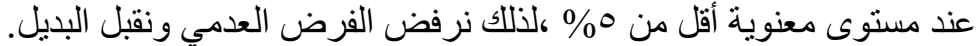

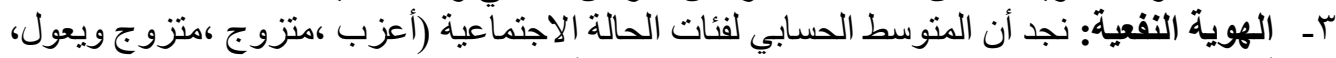

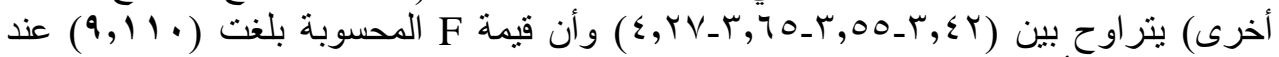

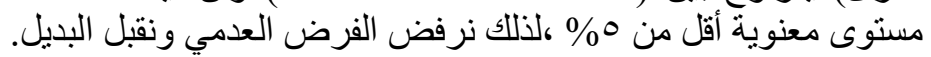

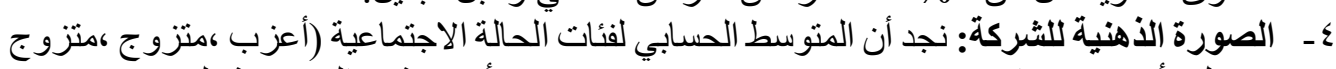

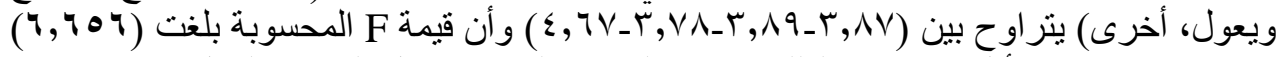

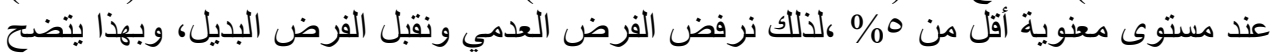

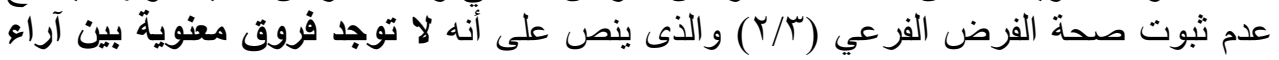

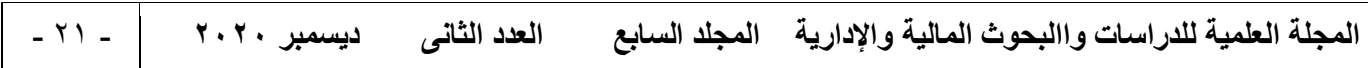


خصائ الهوية التنظيمية وأثرها على التماثل التنظيمى لاى العاملين بشركات قطاع الأعمال العام للغزل والنسيج بوسط الدلتا العاملين في الثركات موضع التطبيق فيما يتعلق بدرجة توافر أبعاد الهوية التنظيمية وفقا للحالة

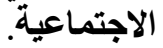

دـ اختبار الفروق المعنوية بين آراء العاملين في الثركات موضع التطبيق فيما يتعلق بدرجة توافر أبعاد التماثل الوظيفي وفقار للحالة الاجتماعية. (الفرض آرضية الرابع).

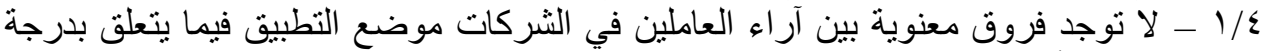

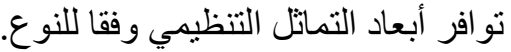

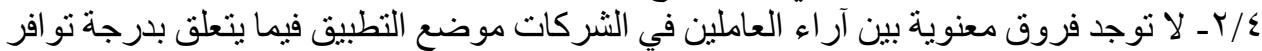

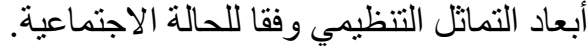

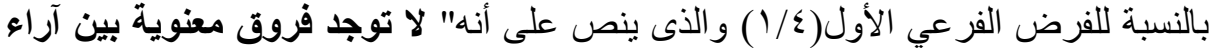

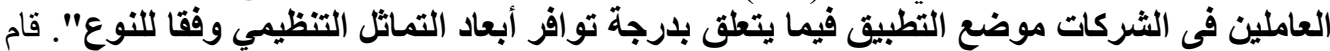

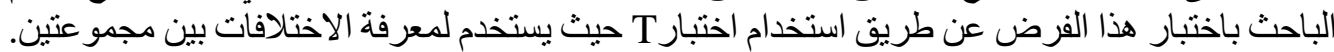

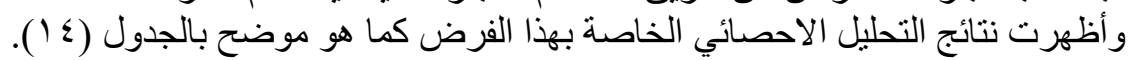

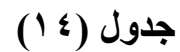

نتائج اختبار (T) لمعرفة أثر النول (1) على أبعاد التماثل التنظيمي

\begin{tabular}{|c|c|c|c|c|c|c|}
\hline معنوية & $\mathbf{T}$ & الانعياري افي & المتوسطي & العدد & الجنس & المتغيرات \\
\hline \multirow{2}{*}{$\cdot, \circ \otimes V$} & \multirow{2}{*}{$1, q 1 r_{-}$} & $\cdot, \sqrt{ } \times$ & $r, 71$ & 1.0 & ذكور & \multirow{2}{*}{ الولاء التنظيمي } \\
\hline & &., $7 \varepsilon$ & $r, V^{\prime}$ & $r \otimes \Lambda$ & اناث & \\
\hline \multirow{2}{*}{$\cdot, \cdots 9$} & \multirow{2}{*}{ r,Y } & $\cdot, \vee \vee$ & $r, 7 V$ & 1.0 & ذكور & \multirow{2}{*}{ التشابة } \\
\hline & & $\cdot, \vee v 1$ & $r, \wedge q$ & $r \bullet \Lambda$ & اناث & \\
\hline \multirow{2}{*}{$\cdot, \cdot r$} & \multirow{2}{*}{ } &., 7. & $r, v \varepsilon$ & 1.0 & ذكور & \multirow{2}{*}{ العضوية } \\
\hline & & $\cdot, \circ V$ & 4,90 & $r \otimes \Lambda$ & انتاث & \\
\hline
\end{tabular}

المصلدر: من اعداد الباحث اعتماد على نتائج التحليل الاحصائي

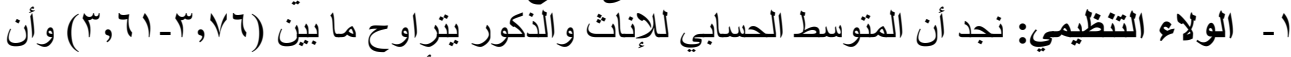

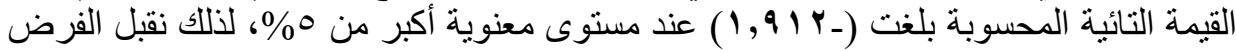

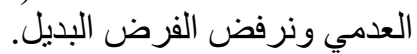

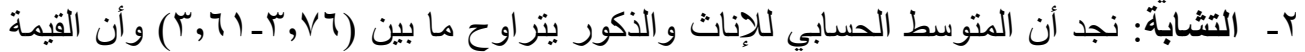

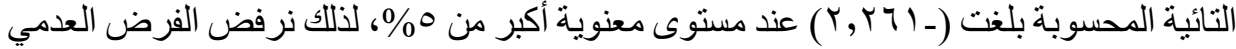

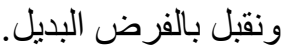

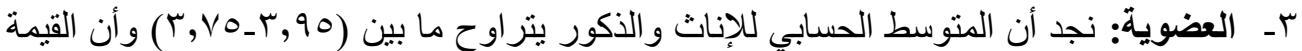

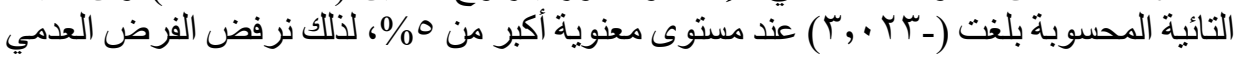

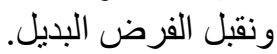

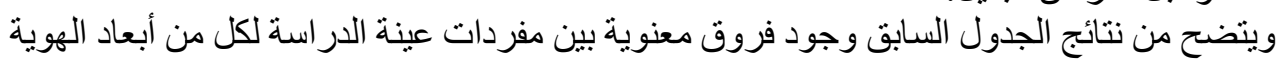

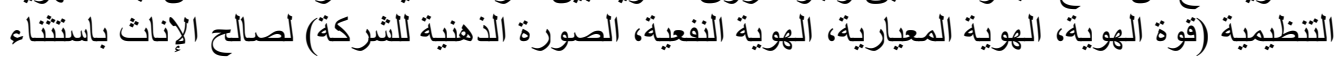

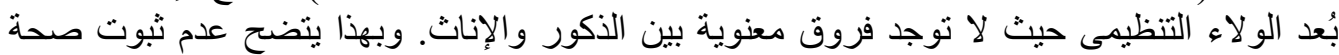

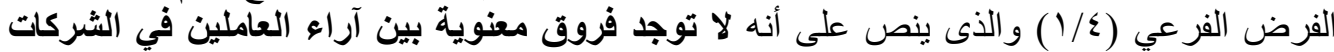

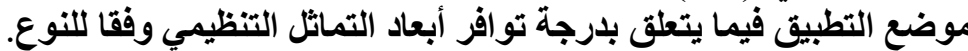

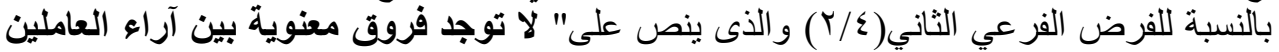

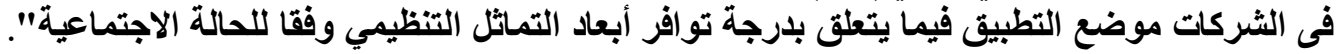

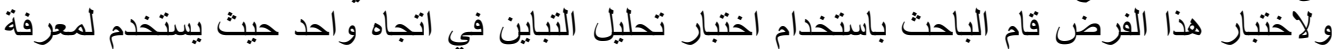

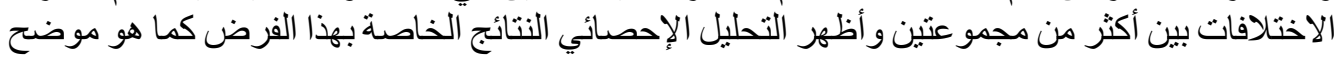

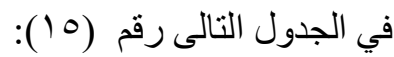

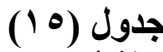

نتائج اختبار تحليل التباين فى اتجاه واحد لمعرفة أثر الحالة الاجتماعية على أبعاد التماثل التنظيمي

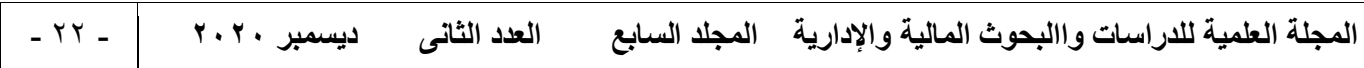


خصائص الهوية التظيمية و أثرها على التماثل التنظيمى لدى العاملين بشركات قطاع الأعمال العام للفزل والنسبج بوسط الدلتا

\begin{tabular}{|c|c|c|c|c|c|c|}
\hline معنوية & $\mathbf{F}$ & الانحرياري & الحسبابي & العدد & الاجتماعالة & المتغيرات \\
\hline \multirow{4}{*}{., .11} & \multirow{4}{*}{$r, r \wedge V$} & $\cdot, \times 7$ & $r, 00$ & 10 & أعزب & \multirow{4}{*}{ لولاء التتظيمي } \\
\hline & &., 71 & $r, \wedge 0$ & $\Delta V$ & متزوج & \\
\hline & & $\cdot, 7 \wedge$ & $r, \uparrow \wedge$ & 187 & متزوج ويعول & \\
\hline & &., 79 & $r, 9 \Lambda$ & 1. & أخرى & \\
\hline \multirow{4}{*}{$\cdots+$} & \multirow{4}{*}{$\vee, \vee q}$. & $\cdot, \wedge 1$ & $r, \leqslant q$ & 10 & أعزب & \multirow{4}{*}{ التشابة } \\
\hline & &., 7 . & $\Gamma, \wedge \wedge$ & $O V$ & متزوج & \\
\hline & & $\cdot, \vee \vee \varepsilon$ & $r, \wedge q$ & 187 & متزوج ويعول & \\
\hline & &., 09 & $\varepsilon, r \varepsilon$ & 1. & أخرى & \\
\hline \multirow{4}{*}{,$\ldots$} & \multirow{4}{*}{$\Lambda, \leftleftarrows \backslash \vee$} & . & r, 70 & 10 & أعزب & \multirow{4}{*}{ العضوية } \\
\hline & &., 0 . & $r, \wedge q$ & $\Delta V$ & متزوج & \\
\hline & & $\cdot, \circ \mathrm{V}$ & 5,90 & 187 & متزوج ويعول & \\
\hline & &.,$\odot \mathrm{V}$ & $\varepsilon, \leqslant 0$ & 1. & أخرى & \\
\hline
\end{tabular}

المصلر: من إعداد الباحث اعتمادا على نتائج التحليل الإحصائي

نلاحظ من الجدول (10) ما لماءي:

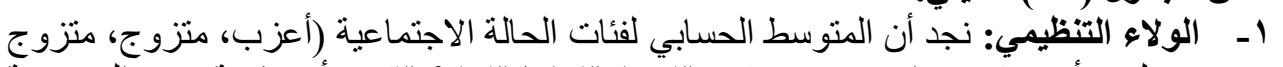

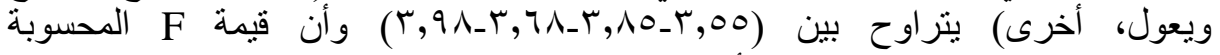

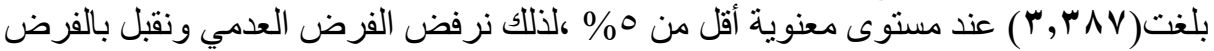

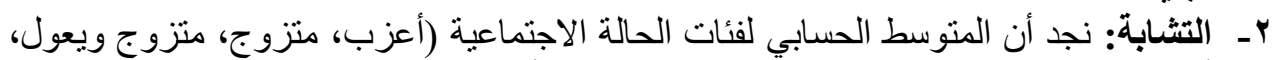

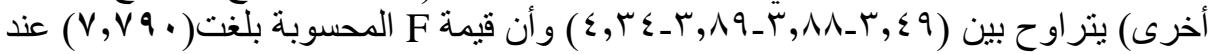

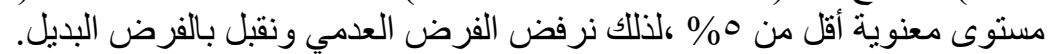

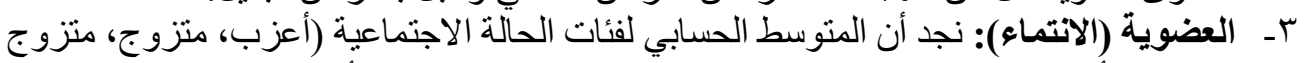

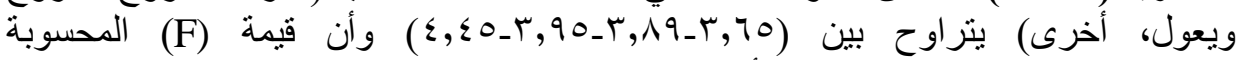

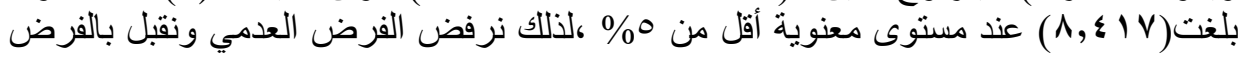

البديل.

ويتضح من نتائج الجدول السابق أنه توجد فروق معنوية بين مفردات عينة الدر اسة حول تو افر أبعاد

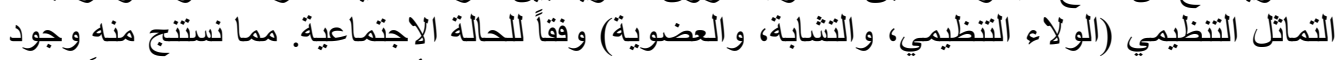
تباين معنوي بين آر اء العاملين في الثركات موضع التطبيق حول تو افر أبعاد التماتل التنظيمي وفقاً للحالة الاجتماعية.

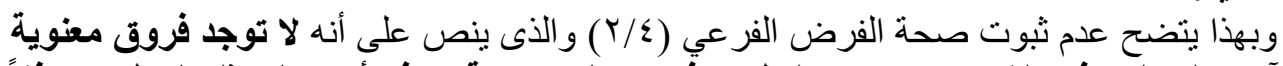

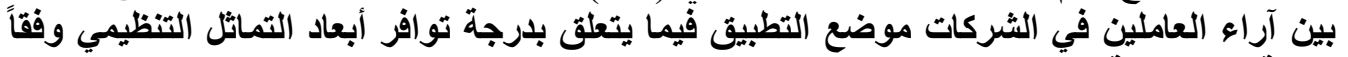
للحالة الاجتماعية.

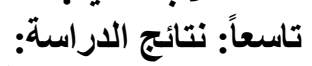

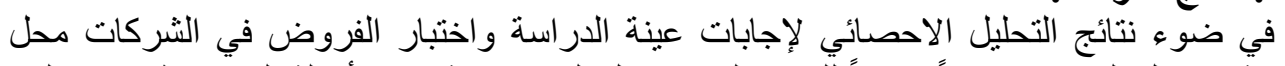

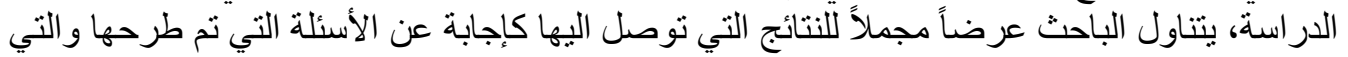

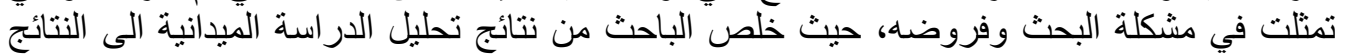

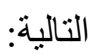

ا - - وجود ارتباط معنوي بين جميع أبعاد الهوية التنظيمبة وجميع أبعاد التمانل التظيمي.

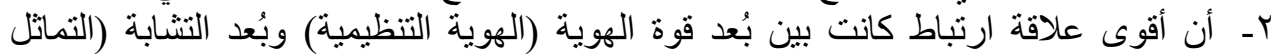
التنظيمي)، و أضعف علاقة ارنباط كانت بين بُعد الصورة الذهن الذهية للثركة (الهوية التنظيمية)

وبُعد الولاء التنظيمي (التماثل التنظيمي).

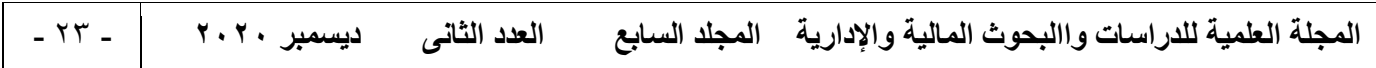




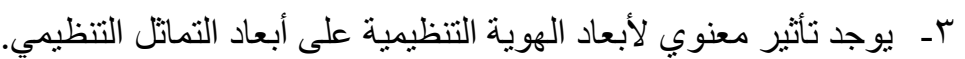

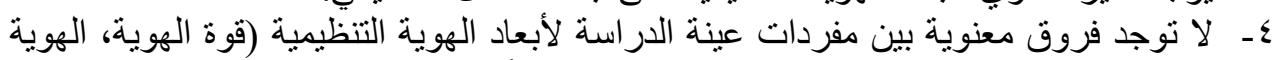

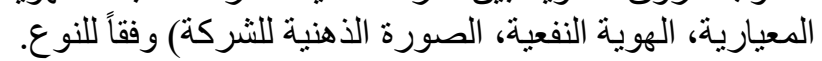

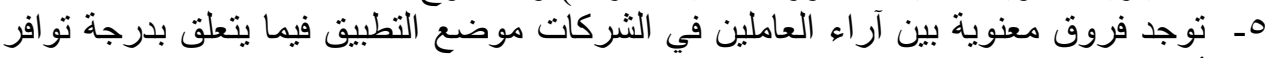
أبعاد الهوية التنظيمية وفقا للحالة الاجتماعية.

T- - وجود فروق معنوية بين مفردات عينة الدراسة لكل من أبعاد الهوية التنظيمية (قوة الهوية،

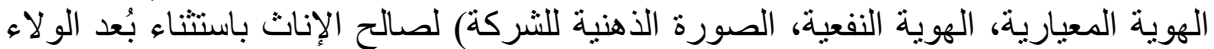
التنظيمى حيث لا توجد فروق معنوية بين الأنية الذكور و الإناث.

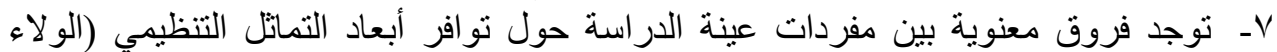
التنظيمي، و التشابة، و العضوية ) وفئة وفقاً للحالة الاجتماعية.

عاثراً: توصيات ألدراسة:

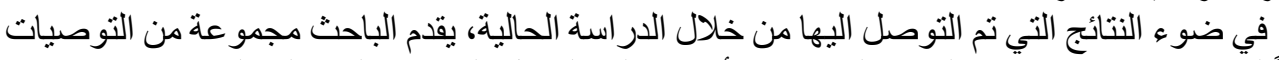

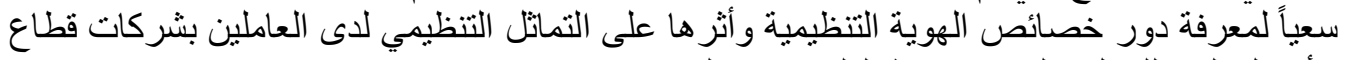

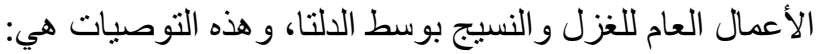

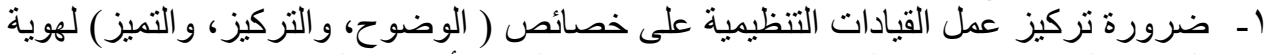

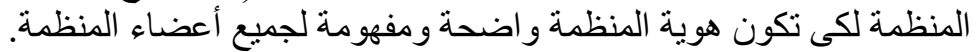

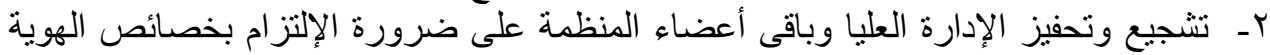

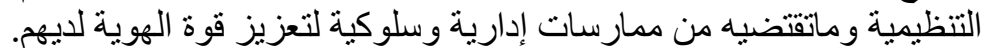

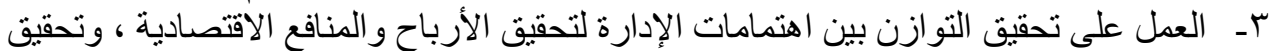

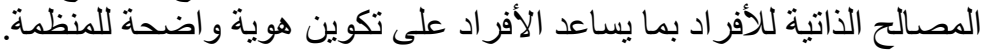

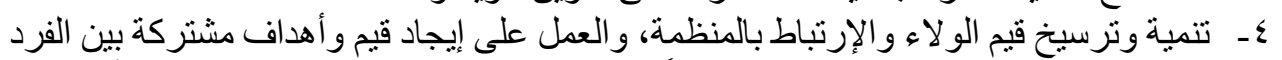

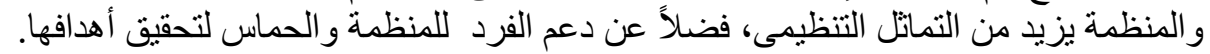

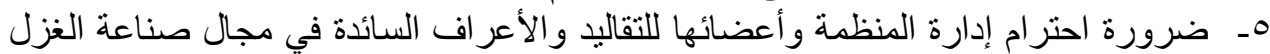
و النسيج داخل وخارج المنظمة لتنأكيد الهوية التنظيمية للمنظمة. 
أولاً: المراجـع العربية:

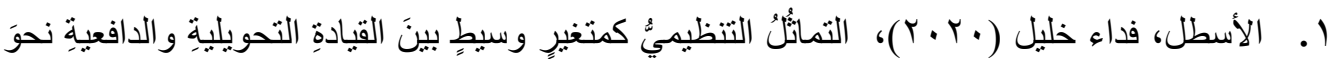

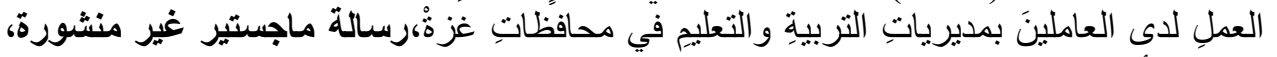

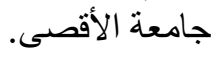

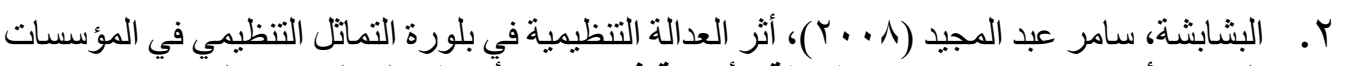

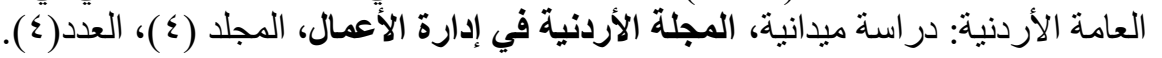

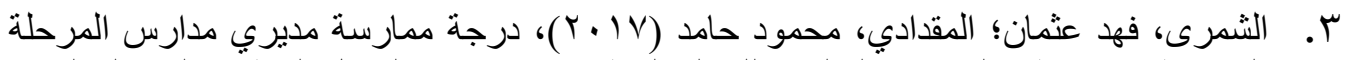

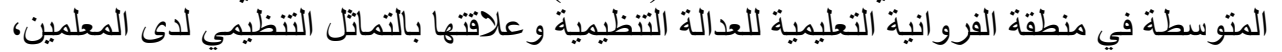

رسالة ماجستير، كلية العلوم التربوية، جامعة آل البيت، الأردن.

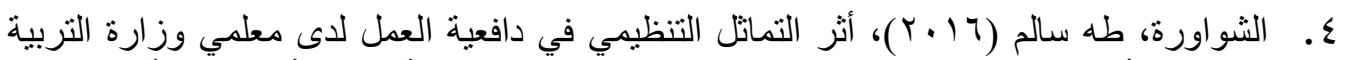

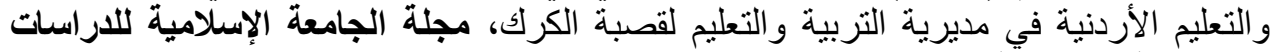

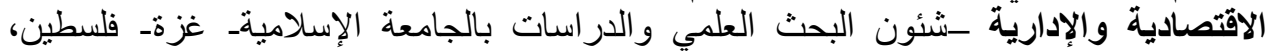

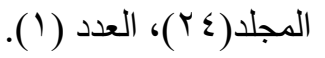

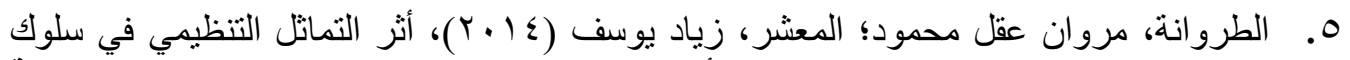

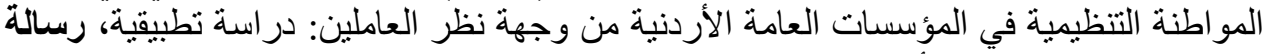
ماجستير، جامعة مؤتة، الأردن.

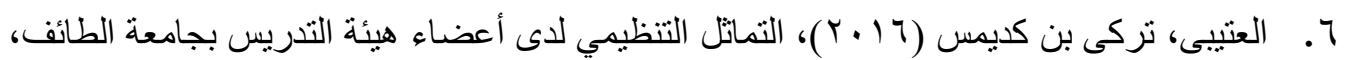

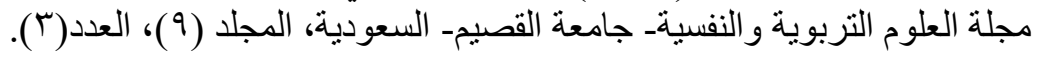

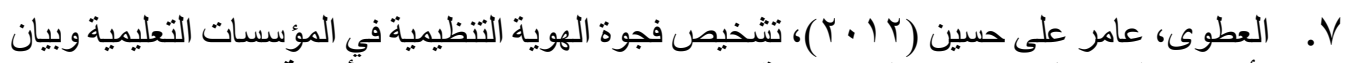

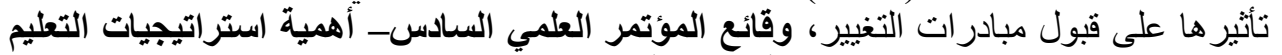

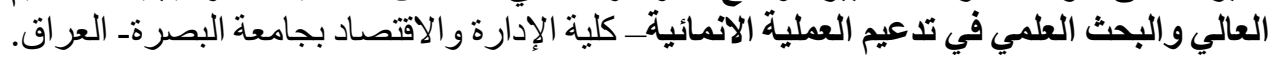

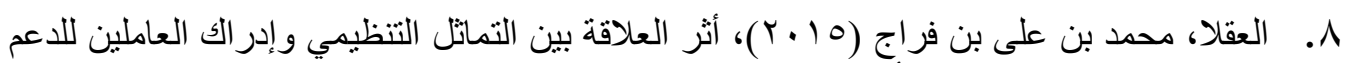

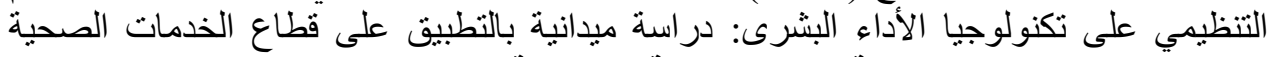

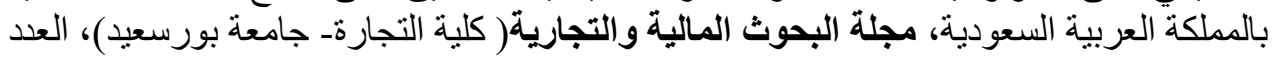

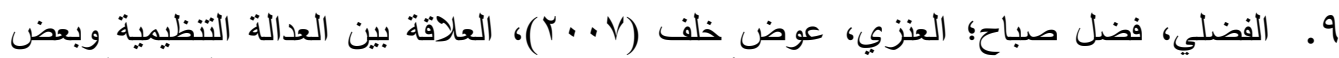

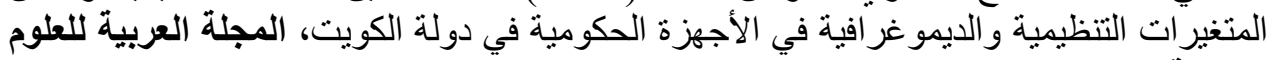

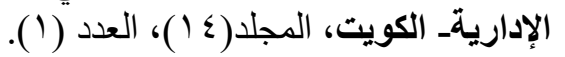

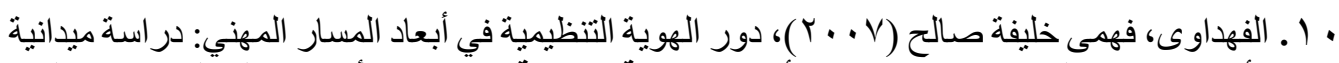

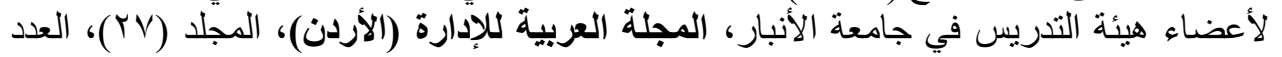

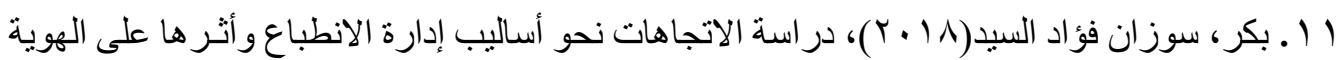

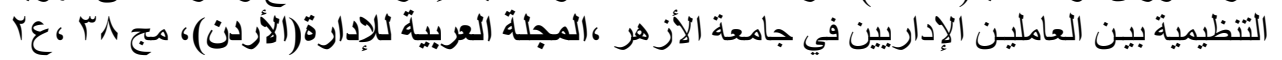

Y ( . جاد، زينب صالح عبدالفضيل (9 (19)، تشكيل الهوية التنظيمية في شركات قطاع الاتصالات

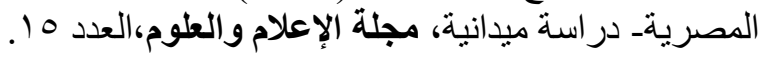

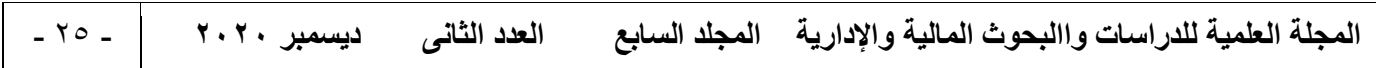


خصائص الهوية التظظيمية و أثرها على التماثل التنظيمى لدى العاملين بشركات قطاع الأعمال العام للفزل والنسبج بوسط الدلتا

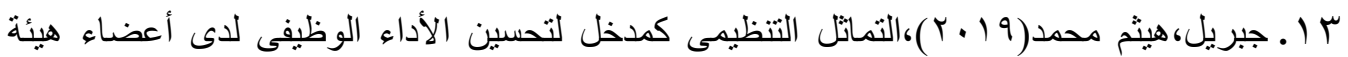

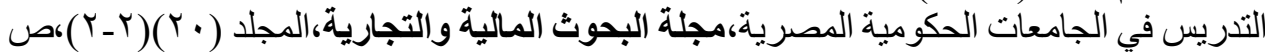

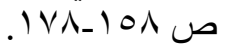

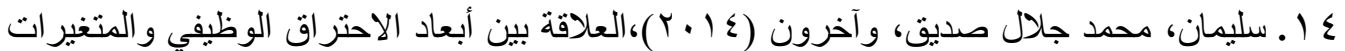

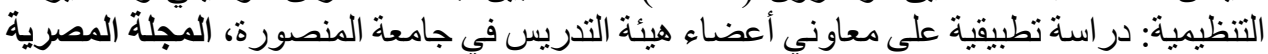

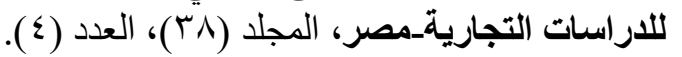
1 ـ طه، عبد الناصر ابر اهيم (10 • ب)، دور خرق العقد النفسي كمتغير وسيط في علاقة العوامل الخمسة

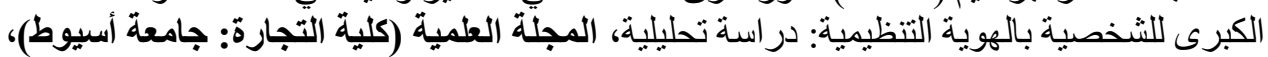

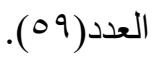

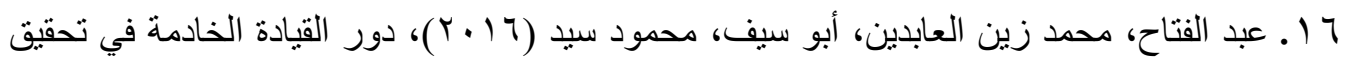

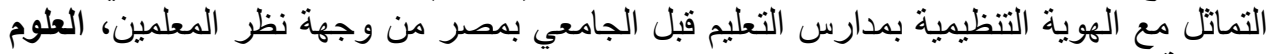

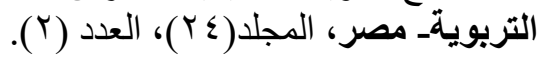

IV

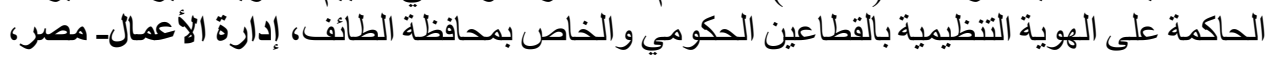

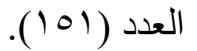

1 1 ـ عبد الو هاب، محمد أبو القمصان محمد (1 . . Y)، العلاقة بين خصائص الهوية التنظيمية و التوحد التنظيمي: دراسة تطبيقية على الأطباء بالمستشفيات الحكومية بمدينة كفر الثيخ، مجلة التجاية التجارة والتمويل، كلية التجارة - جامعة طنطا، العدد ( ).

9 ( ـ علي، عدي احمد صالح(·r.r.r)، الدور الوسيط للهوية التنظيمية في العلاقة بين القيادة التحويلية

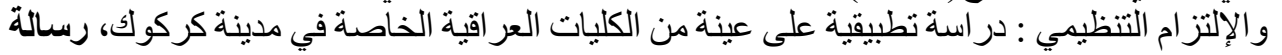
ماجستير غير منشورة، الخرطوم : جامعة السودان للعلوم و التكنولوجيا ، كلية الدر اسات التجارية.

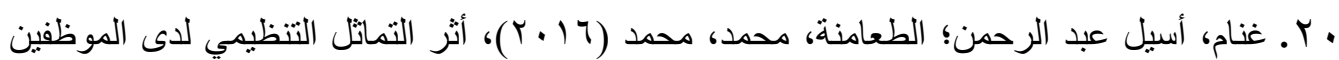

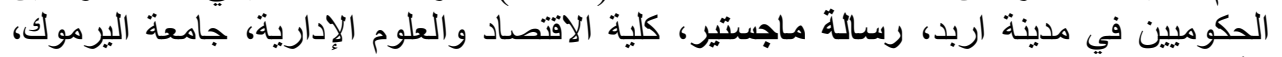

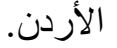

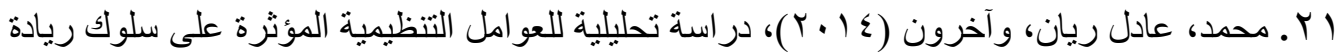

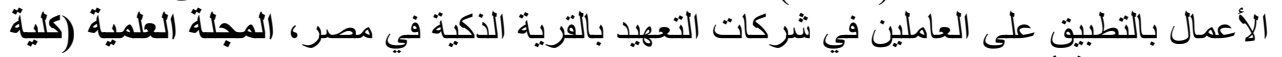

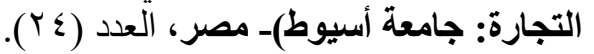

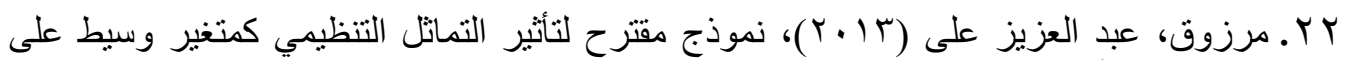

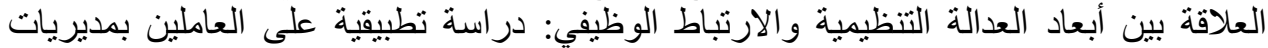

الخدمات بمحافظة كفر الشيخ، مجلة التجارة والتمويل ( كلية التجارة- جامعة طنطا)، العدد(؟) .

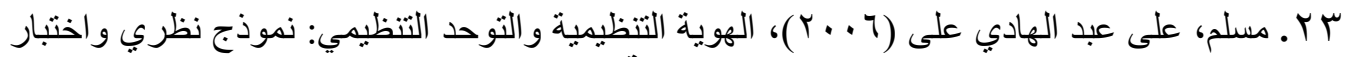
تجريبي على عينة من المنظمات السعودية، مجلة التجارة والتمويل، كلية التجارة- جامعة طنطا،

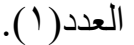

ثُانياً: المراجع الأجنبية:

1. Ahmadi, R. E. (2005). Emerging organizational identity: The process of identity creation in a post divestiture environment, $\mathrm{PhD}$ Dissertation, Alliant International University.

2. Albert, S., Ashforth, B. E., and Dutton, J. E. (2000). Organizational identity and identification: Charting new waters and building new bridges. Academy of management review, 25(1), 13-17.

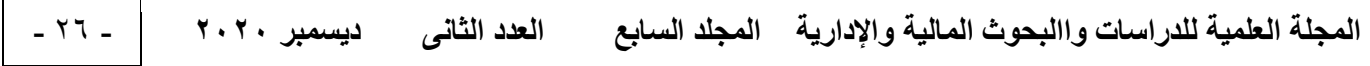


3. Asadullah, M. A., Akram, A., Imran, H., and Arain, G. A. (2017). When and which employees feel obliged: A personality perspective of how organizational identification develops, Journal of Work and Organizational Psychology, 33(2), 125-135.

4. Ashforth, B. E., and Mael, F. A. (1996). Oranizational Identity and Strategy as a Context for the Individual. Advances in strategic management, 13, 1964.

5. Baran, H., and Giderler, C. (2017). A study on determining the influence of organizational identification on organizational justice and organizational silence, International Journal of Asian Social Science, 7(3), 242-258.

6. Cavazotte, F. D. S. C. N., Araujo, F. F. D., \& Abreu, A. L. D. (2017). Organizational identification among Brazilian public employees: a study of the cultural sector, Revistabrasileira de gestão de negócios, 19(64), 289-306.

7. Cheney, G. (1982). On the various and changing meanings of organizational membership: A field study of organizational identification. Communications Monographs, 50(4), 342-362.

8. Erkutlu, Hakan; Chafra, Jamel. (2015), The mediating roles of psychological safety and employee voice on the relationship between conflict management styles and organizational identification, American Journal of Business, 30.(1): 72-91.

9. Fallatah, F., Laschinger, H. K., \& Read, E. A. (2017). The effects of authentic leadership, organizational identification, and occupational coping self-efficacy on new graduate nurses' job turnover intentions in Canada. Nursing outlook, 65(2), 172-183.

10. Gioia, D. A., and Thomas, J. B. (1996). Identity, image, and issue interpretation: Sensemaking during strategic change in academia, Administrative science quarterly, 370-403.

11. Johnson, W. L., Johnson, A. M., and Heimberg, F. (1999). A primary-and second-order component analysis of the organizational identification questionnaire, Educational and psychological measurement, 59(1), 159170.

12. Kerwin, S. (2013), Exploring Organizational Identity and Interpersonal Conflict in Sport Organizations, Journal of Applied Sport Management, 5(2).

13. Loggert, J., and Åhlin, M. (2016). Managing and adapting organizational identity: A qualitative case study using a strategy-as-practice perspective to investigate an IT consultant organization.

14. Mael, F., and Ashforth, B. E. (1992). Alumni and their alma mater: A partial test of the reformulated model of organizational identification, Journal of organizational Behavior, 13(2), 103-123.

15. Martin, K. D., Johnson, J. L., and French, J. J. (2011), Institutional pressures and marketing ethics initiatives: the focal role of organizational identity. Journal of the Academy of MarketingScience, 39(4), 574-591.

16. Matherne, C., Waterwall, B., Ring, J. K., \& Credo, K. (2017). Beyond organizational identification: The legitimization and robustness of family 
خصائص الهوية التنظيمية وأثرها على التماثل التنظيمى لدى العاملين بشركات قطاع الأعمال العام للفزل والنسبج بوسط الدلتا

identification in the family firm, Journal of Family Business Strategy, 8(3), 170-184.

17. Meleady, R., \& Crisp, R. J. (2017). Take it to the top: Imagined interactions with leaders elevates organizational identification, The Leadership Quarterly, 28(5), 621-638.

18. Mujib, H. (2017). Organizational Identity: An Ambiguous Concept in Practical Terms. Administrative Sciences, 7(3), 28.

19. Taskiran, E. (2017). The Moderating Role of Organizational Identification on the Relationship between Perceived Organizational Career Management and Intention to Leave. International Journal of Business and Management, 12(11), 73.

20. Voss, Z. G., Cable, D. M., and Voss, G. B. (2006). Organizational identity and firm performance: What happens when leaders disagree about "who we are?'. Organization Science, 17(6), 741-755.

21. Wang, H. J., Demerouti, E., \& Le Blanc, P. (2017). Transformational leadership, adaptability, and job crafting: The moderating role of organizational identification, Journal of Vocational Behavior, 100, 185195.

22. Zundel, M., Holt, R., and Popp, A. (2016). Using history in the creation of organizational identity, Management \& Organizational History, 11(2), 211-235.

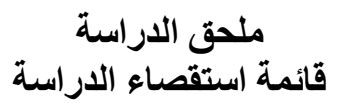

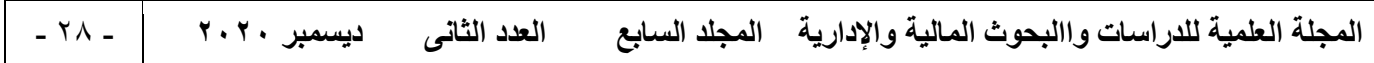


خصائص الهوية التظيمية وأثرها على التماثل التنظيمى لاى العاملين بشركات قطاع الأعمال العام للغزل والنسبج بوسط الدلتا المتغير المستقل: الهوية التنظيمية:

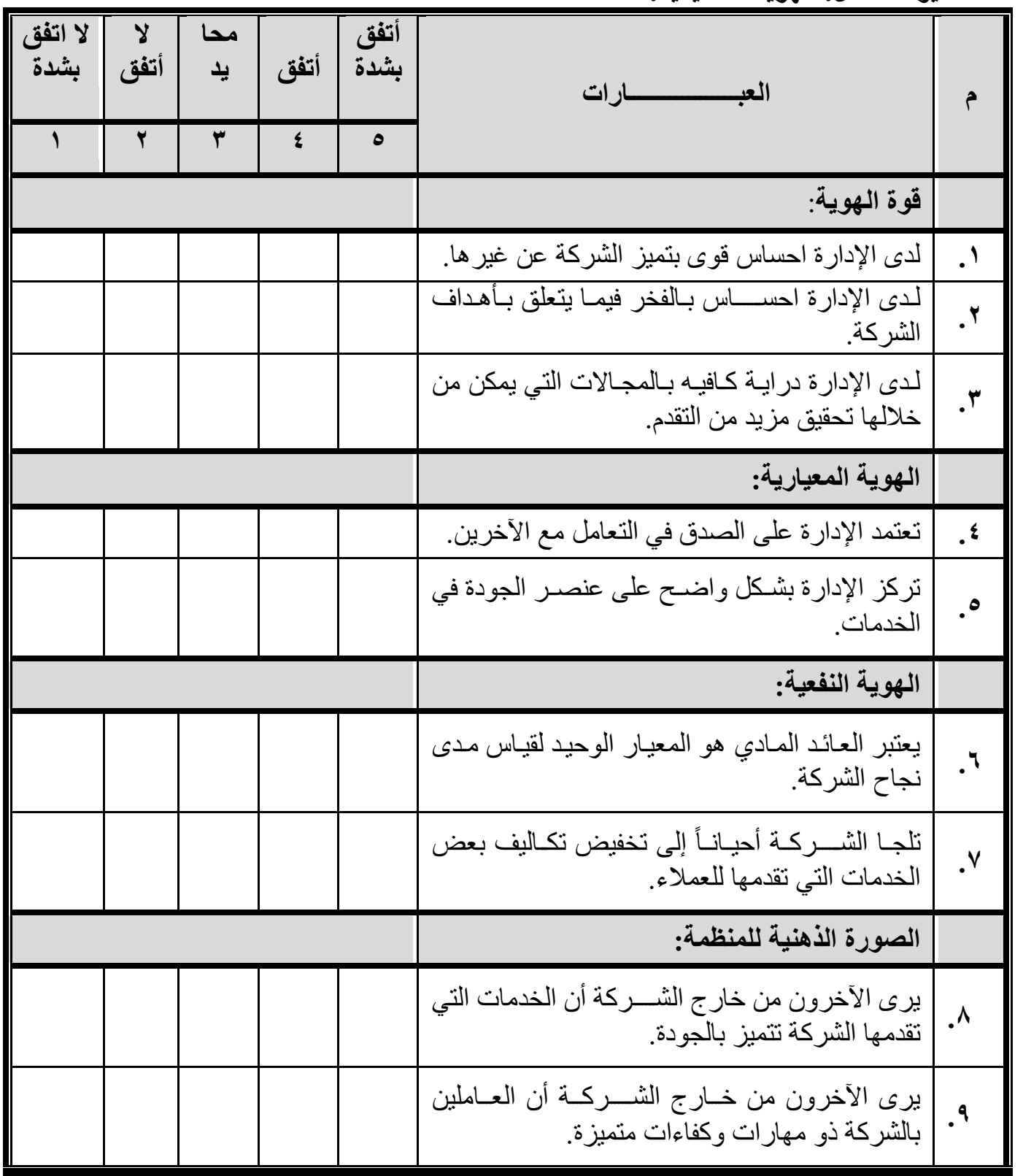




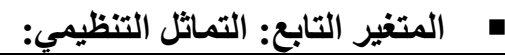

\begin{tabular}{|c|c|c|c|c|c|c|}
\hline لا بشدة & ل لا أتقق & متأكيد & أتفق & بثدة أنقق & \multirow[t]{2}{*}{ العبــــــــــــــارات } & \multirow[t]{2}{*}{ p } \\
\hline \multirow[t]{9}{*}{1} & $r$ & $r$ & $\varepsilon$ & 0 & & \\
\hline & & & & & الولاء التنظيمي: & \\
\hline & & & & & أهتم بمستقبل شركتي بجدية. & .1 \\
\hline & & & & & 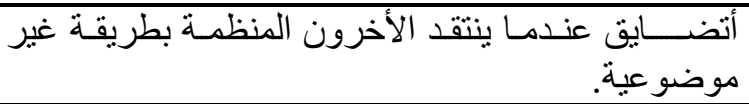 &.$r$ \\
\hline & & & & & أشعر بولائي المستمر للشركة. & r \\
\hline & & & & & 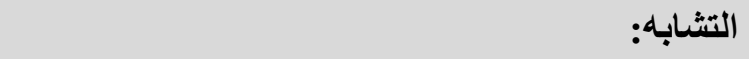 & \\
\hline & & & & & أبذل أقصى جهد لتحقيق أهداف المنظمة. &.$\varepsilon$ \\
\hline & & & & & أعمل في الشركة من أجل تحقيق رسالتها. & .0 \\
\hline & & & & & توجهاتي وتطلعانتي. & .7 \\
\hline & & & & & العضوية ( الانتماء). & \\
\hline & & & & & لدى انتماء للشركة التي أعمل فيها. &.$V$ \\
\hline & & & & & أشعر بسرور كبير لأنني في هذه الشركة. &.$\wedge$ \\
\hline & & & & & أشركة. نفسـي للأخرين بالقول: أعمل في الثـركة أنا من & .9 \\
\hline
\end{tabular}

